\title{
Identification and characterization of antibacterial compound(s) of cockroaches
}

\section{(Periplaneta americana)}

\author{
${ }^{\wedge}$ Salwa Mansur Ali, ${ }^{\wedge}$ Ruqaiyyah Siddiqui, ${ }^{1}$ Seng Kai Ong, ${ }^{2}$ Mohammad Raza Shah, ${ }^{2}$ Ayaz \\ Anwar, ${ }^{1}$ Peter J. Heard, ${ }^{1}$ Naveed Ahmed Khan
}

\begin{abstract}
${ }^{1}$ Department of Biological Sciences, Faculty of Science and Technology, Sunway University, Malaysia; ${ }^{2}$ International Center for Chemical and Biological Sciences, H.E.J. Research Institute of Chemistry University of Karachi, Pakistan.
\end{abstract}

\section{Short title: Antibacterial compound(s) of cockroaches}

*Corresponding address: Department of Biological Sciences, Faculty of Science and

Technology, Sunway University, Selangor, 47500, Malaysia. Tel: 60-(0)3-7491-8622. Ext: 7176.

Fax: 60-(0)3-5635-8630. E-mail: naveed5438@ gmail.com

\section{^ Both contributed equally to this study}




\section{ABSTRACT}

Infectious diseases remain a significant threat to human health, contributing to more than 17 million deaths, annually. With the worsening trends of drug resistance, there is a need for newer and more powerful antimicrobial agents. We hypothesized that animals living in polluted environments are potential source of antimicrobials. Under polluted milieus, organisms such as cockroaches encounter different types of microbes, including superbugs. Such creatures survive the onslaught of superbugs and are able to ward off disease by producing antimicrobial substances. Here, we characterized antibacterial properties in extracts of various body organs of cockroaches (Periplaneta americana) and showed potent antibacterial activity in crude brain extract against methicillin-resistant Staphylococcus aureus and neuropathogenic E. coli K1. The size-exclusion spin columns revealed that the active compound(s) are less than $10 \mathrm{kDa}$ in molecular mass. Using cytotoxicity assays, it was observed that pre-treatment of bacteria with lysates inhibited bacteria-mediated host cell cytotoxicity. Using spectra obtained with LC-MS on Agilent 1290 infinity liquid chromatograph, coupled with an Agilent 6460 triple quadruple mass spectrometer, tissues lysates were analyzed. Among hundreds of compounds, only a few homologous compounds were identified that contained isoquinoline group, chromene derivatives, thiazine groups, imidazoles, pyrrole containing analogs, sulfonamides, furanones, flavanones, and known to possess broad-spectrum antimicrobial properties, and possess antiinflammatory, anti-tumour, and analgesic properties. Further identification, characterization and functional studies using individual compounds can act as a breakthrough in developing novel therapeutics against various pathogens including superbugs.

Keywords: Cockroach, Antibacterials; Superbugs. 


\section{Introduction}

Antibiotic resistance is one of the world's most pressing public healthcare problems (WHO 2002). In recent decades, almost every variant of human pathogenic bacteria has become resistant and/or less vulnerable to available antibiotic treatment, threatening new infectious diseases or emergence of super-strains that are difficult to eradicate (Alanis 2005; Nordmann et al. 2007). Moreover, the current decline in the identification of new antibacterial molecules presents a clear and present danger (Alanis 2005; Nordmann et al., 2007; Devasahayam et al. 2010). In particular, the prevalence of multiple drug-resistant bacterial strains in hospital and community settings is a significant challenge to human health (Alanis 2005; Nordmann et al., 2007; Devasahayam et al. 2010). Among a plethora of multiple drug-resistant bacteria, methicillin-resistant Staphylococcus aureus (MRSA) poses a significant threat to human and animal health (Enright 2003). MRSA is a Gram-positive bacteria, that is resistant to many antibiotics and possesses the ability to produce skin and tissue infections that are often nosocomial in nature (Pantosti et al. 2009). Likewise, neuropathogenic E. coli $\mathrm{K} 1$ is a leading cause of neonatal meningitis contributing to significant morbidity and mortality, despite advances in antimicrobial chemotherapy (Lee et al. 2011).

We hypothesize that animals living in unsanitary and unhygienic conditions have developed ways of protecting themselves against pathogenic microorganisms (Lee et al. 2011; Sagheer et al. 2014; Bulet et al. 1999; Wilson et al. 1999; Khan et al. 2008). For example, insects such as cockroaches thrive in unhygienic environments. The fact that cockroaches share the environmental niches with humans and animals suggests their routine exposure to infectious agents important to human health. The ability of cockroaches to flourish under such threats and 
ward off diseases, indicates their resistance to pathogenic microbes including superbugs as well as toxicants and hazardous materials. Such organisms could be a good source of antibacterials against human pathogens. Insects represent $70 \%$ of living fauna and most diverse among the entire animal Kingdom. Insects such as cockroaches have survived millions of years, and withstood catastrophic events (for comparison, humans have been on the planet for 10,000 years), suggesting their ability to adapt and resist environmental threat. These findings support our hypothesis, to search for potential antimicrobials in such creatures. To this end, our studies suggested that insects such as locusts and cockroaches possess antimicrobials. We characterized antibacterial properties of organ extract of cockroaches (Periplaneta americana), and tested their effects on human cells, with a view to determine chemical and structural identities as potential therapeutic agents to treat infections.

\section{Materials and Methods}

\section{Bacterial cultures}

A clinical isolate of methicillin-resistant Staphylococcus aureus (MRSA) was used in the present study (Malaysian Type Culture Collection 381123). MRSA strain used in this study was originally derived from blood cultures, obtained from the Luton \& Dunstable Hospital NHS Foundation Trust, Luton, England, UK. The sensitivity patterns of MRSA demonstrated its susceptibility to gentamicin, ciprofloxacin, vancomycin and resistance to amoxicillin, augmentin, cephalaxin, cephtazidim, penicillin, flucloxacillin, tetracycline, and erythromycin. In addition, a Gram negative neuropathogenic Escherichia coli (a cerebrospinal fluid isolate from a meningitis patient; 018:K1:H7), strain E44 was used as described previously (Malaysian Type Culture 
Collection 710859). Bacteria were cultured in Luria-Bertani (LB) broth and grown overnight at $37^{\circ} \mathrm{C}$, prior to experiments as previously described (Khan et al. 2008).

\section{Organ lysates of cockroaches}

Cockroaches (Periplaneta americana) were reared on a diet of dried dog food pellets and were housed in glass fronted metal cages in the dark. The cages were kept in a temperatureregulated insectary at $30^{\circ} \mathrm{C}$. For dissections, all instruments were sterilized in $70 \%$ ethanol prior to and during each dissection. Cockroaches were immobilized by exposure to $4^{\circ} \mathrm{C}$ for $15 \mathrm{~min}$. Cockroaches were immobilized by removal of legs and wings and securing to a dissection plate, ventral side up, using a pin on either side of the thorax and one through the distal abdomen. The head and legs were removed, prior to a longitudinal incision made down the midline of the abdomen to expose the fat body tissue, a sample of which was removed aseptically. The thoracic cuticle was opened up with a flap-shaped incision to obtain the haemolymph from the cockroach body cavity using a pipette. The upper hind leg of the cockroach was opened up with a longitudinal incision to expose muscle tissue, a sample of which was aseptically removed. The removed cockroach head was dissected to obtain the intact brain aseptically.

Insect tissue samples were collected in $500 \mu \mathrm{L}$ of sterile water in batches of samples obtained from 500 cockroaches. The samples were kept on ice during dissection and treated in an identical manner. An estimate was made by eye/weight to ensure that the mass of each tissue was approximately similar. The samples were subjected to four cycles of freeze-thawing in order to cause cellular disruption and lysis. The thawing period was kept as brief as possible and organ extracts were kept cold $\left(4^{\circ} \mathrm{C}\right)$ before re-freezing. The samples were then homogenized aseptically with a tissue grinder, prior to centrifugation at $10,000 \mathrm{~g}$ for $30 \mathrm{~min}$ at $4{ }^{\circ} \mathrm{C}$. The 
supernatant (crude extract) was then collected, filtered sterilized using $0.2 \mu \mathrm{m}$ pore size filter, and protein concentration was determined using a Bio-Rad Protein Assay kit. Finally, lysates were stored at $-20^{\circ} \mathrm{C}$ until needed for antibacterial bioassay testing.

\section{Antibacterial assays}

To determine the effects of crude extracts of various organ lysates on bacterial viability, antibacterial assays were performed as described previously (Khan et al. 2008). Briefly, the optical density of bacterial broth cultures was adjusted to 0.22 at $595 \mathrm{~nm}$ using a spectrophotometer (equivalent to $10^{8}$ colony forming units per $\mathrm{mL}$ and confirmed by plating on nutrient agar plates). Approximately $10^{6}$ colony forming units (c.f.u.), suspended in $10 \mu \mathrm{L}$ were incubated with different concentrations of various organ lysates of cockroaches at $37^{\circ} \mathrm{C}$ for $2 \mathrm{~h}$. Following this, bacteria were serially diluted and enumerated by plating on nutrient agar plates (Khan et al. 2008). For negative controls, bacteria were incubated in PBS alone and for positive controls, bacteria were incubated with $100 \mu \mathrm{g}$ per $\mathrm{mL}$ of gentamicin. Percentage bactericidal effects were determined as the percentage of bacteria surviving relative to the control: 100 - (cfu recovered / original inoculum x 100).

\section{Human brain microvascular endothelial cell (HBMEC) cultures}

The primary HBMEC were cultured in RPMI-1640 containing 10\% heat inactivated fetal bovine serum, $10 \% \mathrm{Nu}$-serum, $2 \mathrm{mM}$ glutamine, $1 \mathrm{mM}$ Na-pyruvate, $100 \mathrm{U}$ penicillin per $\mathrm{mL}$, $100 \mu \mathrm{g}$ streptomycin per $\mathrm{mL}$, non-essential amino acids and vitamins as previously described (Khan and Siddiqui, 2009). For cytotoxicity assays, HBMECs were cultured in 24-well plates by inoculating $5 \times 10^{5}$ cells per well per $\mathrm{mL}$ and incubating them at $37^{\circ} \mathrm{C}$ with $5 \% \mathrm{CO}_{2}$, which resulted in the formation of complete monolayers within $48 \mathrm{~h}$. 


\section{Cytotoxicity Assay}

Cytotoxicity assay were performed as previously described (Khan and Siddiqui, 2009). Briefly, assays were performed in 24 well plates containing confluent HBMEC monolayers. The organ lysates alone, bacteria alone, or bacteria treated with lysates were added to confluent HBMEC layers (final volume of $500 \mu \mathrm{L}$ RPMI-1640). For treatment, bacteria were incubated with gentamicin $(100 \mu \mathrm{g}$ per $\mathrm{mL})$ or lysates $(100 \mu \mathrm{g}$ per $\mathrm{mL})$ for $2 \mathrm{~h}$ at $37^{\circ} \mathrm{C}$, followed by incubation with $\mathrm{HBMEC}$ monolayers. Plates were incubated at $37^{\circ} \mathrm{C}$ in a $5 \% \mathrm{CO}_{2}$ incubator for $20 \mathrm{~h}$. After this incubation, the supernatants were collected from each well, centrifuged to remove cellular debris and then cytotoxic effect were determined by estimating the amount of lactate dehydrogenase release from HBMEC using Cytotoxicity Detection kit (Roche Applied Sciences). The percent cytotoxicity was calculated as follows: $\%$ cytotoxicity $=($ sample value control value) / (total LDH release - control value) X 100. Control values were determined by incubating HBMEC monolayers with RPMI-1640 alone and total LDH release was obtained by completely lysing the HBMEC using $1 \%$ Triton X-100. To determine the molecular mass of the active molecule(s), crude brain lysates were filtered through $30 \mathrm{kDa}$, and $10 \mathrm{kDa}$ molecular weight cut off Spin-X UF columns (Corning). Both the elutate and retentate were used in the aforementioned antibacterial assays.

\section{Liquid Chromatography Mass Spectrometry LC-MS): separation and analysis}

All samples were analyzed using a LC-MS on Agilent 1290 infinity liquid chromatograph (Agilent Technologies, Wilmington, DE), coupled with an Agilent 6460 triple quadruple mass spectrometer. Separation of compounds were achieved using reverse-phase HPLC, with a Merck $\mathrm{C}-18$ column of particle size $3 \mu \mathrm{m}(5.5 \mathrm{~cm}$ length and i.d. of $4.6 \mathrm{~mm})$ at $25^{\circ} \mathrm{C}$, and equilibrated 
with $90 \%$ solvent A ( $0.1 \%$ formic acid in MiliQ water) and $10 \%$ solvent B $(0.1 \%$ formic acid in $\mathrm{MeOH})$. A flow rate of $0.6 \mathrm{~mL}$ per min with a linear gradient was used as follows: $10 \%$ solvent B for 4 min, $80 \%$ solvent B over the course of 3.2 min, and $10 \%$ solvent B for 2.8 min. The total run time was 14 min, including a 5 min equilibration time.

The compounds were ionized using ESI + jet stream ion mode with the QQQ analyzer. The parameters of ion source were set as follows: capillary voltage at $4500 \mathrm{~V}$, sheath gas flow at $8 \mathrm{~L}$ per min, fragmentor voltage $135 \mathrm{~V}$, gas temperature at $350^{\circ} \mathrm{C}$, gas flow at $8 \mathrm{~L}$ per min, and nebulizer gas at 40 psi and detector used was MCP Microchannel Plate detector, while blank used after each sample of composition $50 \% \mathrm{MeOH}+50 \%$ MiliQ water.

\section{Identification of compounds through matching with library}

Water soluble and methanol-extracted lysates of brain, haemolymph, and muscles of cockroaches were subjected to LC-MS analysis as described above, to obtain the chromatograms and the prospective mass spectra of every separated fraction of the mixture of compounds. The MS spectra for the compounds present in water soluble and methanol-extracted lysates were run against the NIST Mass Spectral Search Program-2009 version 2.0f (National Institutes of Standard and Technology, Gaithersburg, MD) for the identification of homologous compounds through Agilent Mass Hunter software, while keeping in view compensation needed for charges in positive ESI MS as well as electron fragmentations, to ensure searches for the correct parent mass. Reported biological activities of the compounds identified and their novelty were determined with the help of Scifinder software. 


\section{Results}

Cockroach brain crude lysates exhibit potent bactericidal activity against MRSA and neuropathogenic E. coli K1

The crude extracts of cockroach fat body, muscle, and brain were prepared and tested along with aspirated haemolymph in antibacterial bioassays against MRSA. Fat body and muscle lysates showed no bactericidal activity against MRSA and E. coli $\mathrm{K} 1$ at $100 \mu \mathrm{g}$ per mL, while haemolymph exhibited $35 \% \pm 5.1$ and $20 \% \pm 3.5$ bactericidal effects, against MRSA and E. coli K1 respectively. In contrast, brain extracts exhibited more than $90 \%$ bactericidal effects against both MRSA and neuropathogenic E. coli K1 (Fig. 1).

Partial characterization of cockroach brain crude lysates and their effects on human cells

When crude brain lysates were filtered through $30 \mathrm{kDa}$, and $10 \mathrm{kDa}$ molecular weight cut off Spin-X UF columns, the antibacterial activity was observed in elutate, suggesting that antibacterial compound(s) are less than $10 \mathrm{kDa}$ in molecular mass. To assess potential cytotoxicity to human cells, lysates were added to HBMEC monolayers and lactate dehydrogenase, a marker for cellular lysis, was measured using a Roche cytotoxicity detection kit. When incubated with MRSA or neuropathogenic E. coli K1 alone, more than 70\% HBMEC cytotoxicity was observed (Fig. 2). In contrast, MRSA or neuropathogenic E. coli K1 pretreated with gentamicin or lysates followed by incubation with HBMEC produced minimal host cell damage. Notably, lysates alone showed minimal HBMEC cytotoxicity, indicating selective toxicity against bacteria tested. 
Identification of compound(s) present in cockroach lysates using liquid chromatography mass spectrometry

The brain, haemolymph, and muscles lysates of cockroaches were processed for water and methanol extractions and subjected to LC-MS (Agilent Technologies 6460 Triple Quadrupole LC/MS) for qualitative analyses. Figure 3 shows spectra from respective extractions. These compounds were separated based on $\mathrm{m} / \mathrm{z}$ ratio and retention time in the column. The data obtained from the LC-MS for brain lysates contained over 168 peaks for water soluble and over 193 peaks for methanol-extracted brain lysates (Fig. 3). Similarly, the data obtained from LC-MS for haemolymph lysates contained over 182 peaks for water soluble and over 172 peaks for methanol-extracted haemolymph lysates (Fig. 3). Similarly, the data obtained for muscles extract contained over 180 peaks for water soluble and 190 peaks for methanol soluble lysates of muscles (Fig. 3).

For brain lysates, among hundreds of compounds, 5 were identified from water extracted lysates, and 15 generated from LC-MS were identified from methanol-extracted compounds (Table 1). Similarly, for haemolymph lysates, among hundreds of compounds, 19 were identified from water-extracted lysates, and 18 from methanol-extracted compounds (Table 2). For muscles lysates, among hundreds of compounds, 12 were identified from water soluble lysates, and 18 from methanol-extracted compounds were identified using LC-MS (Table 3).

The compounds were searched through Scifinder software to determine any reported biological activity. Among various homologous compounds from brain lysates, many of them were shown to possess biologically active molecules (Table 1). For example, compounds 1, 2, 3, $6,10,13,15,16,17,18$, and 19 possess antimicrobial activities against various Gram positive 
and Gram negative bacteria including, Listeria monocytogenes, Bacillus subtilis, Salmonella typhimurium, Staphyloccus aureus, Pseudomonas aeruginosa, E. coli, Klebsiella pneumonia, Bacillus mycoides, Proteus vulgaris, Proteus mirabilis, Enterobacter cloacae, Enterococcus faecalis, Morganella morganii, Providencia stuartii, fungi including Candida albicans, Curvularia lunata, Aspergillus flavus, Aspergillus niger, Verticillium alboatrum, Colletrichurm lagenarium, Alternaria alternate, Phytophora infestans, Dermatophytes etc., viruses including Parainfluenza virus, Influenza A virus, Respiratory syncytial virus, Herpes virus etc. Additionally, compounds homologous to $1,2,6,11,13,16$, and 17 are shown to possess antitumour properties against various types of cancers, including oral squamous cell carcinoma, breast cancer, hepatic carcinoma, nasopharyngeal carcinoma, prostate cancer, lung cancer, intestinal tumour etc. while some homologous compounds are shown to exhibit biological activities such as anti-diabetic, anti-inflammatory, anti-platelet aggregation, antioxidant, and analgesic activities (Table 1).

The 5 compounds identified in water extracted brain lysates, i.e., Cpd1: 6,7-dimethoxy-1methoxymethyl-3,4-dihydroisoquinoline, Cpd2: (3S,6S,6aS,8S,10S,11aR,12R,12aS,13S)-1ethyl-8,10,13-trimethoxy-3-(methoxymethyl)tetradecahydro-1H-3,6a,12-(epiethane[1,1,2]triyl)7,9-methanonaphtho[2,3-b]azocine-6,11a,12-triol, and Cpd3: 3,6-Dimethylbenzofuran-4(5H)-ol, Cpd4: 3-((6-methoxy-1,2,3,4-tetrahydroisoquinolin-1-yl)methyl)phenol, and Cpd5: 4-benzyl-4,5dihydroisoxazole, have reported biological activities mentioned above. Among the 15 compounds identified from brain methanol extracts, 3 of them (Cpd11: 2-Amino-3,6dimethylimidazo[4,5-b]pyridine, Cpd18: 2-isopropoxy-5-phenyl-1,3,4-oxadiazole, and Cpd20: 4,4'-(iminomethylene)bis(N,N-dimethylaniline) have reported biological activities. However, Cpd8: 1,4-dihydro-2,3-benzoxathin-3-oxide, and Cpd9: 2,2,4,7a-tetramethyl-6-(phenylsulfonyl)- 
3a,4,5,7a-tetrahydrobenzo[d][1,3] dioxole do not have any reported biological activities. The remaining 10 compounds have homologous structures, reported in the literature with various biological activities (Table 1).

For haemolymph lysates, several homologous compounds were shown to possess biologically active molecules. For example, compounds 1, 2, 3, 4, 6, 10, 12, 14, 15, 16, 19, 20, $23,24,26,28,29,30,31,32,33$, and 37 were shown to possess antimicrobial activities against broad range of microorganisms including bacteria such as Bacillus subtilis, Bacillus anthracis, Bacillus mycoides, Bacillus cereus, Enterococcus feacalis, Staphylococcus aureus, Salmonella typhi, Proteus vulgaris, Pseudomonas aeruginosa, Pseudomonas fluorescens, Pasturella multicoda, E. coli, Klebsiella pneumoniae, Listeria monocytogenes etc., fungi such as Aspergillus niger, Fusarium proliferatum, Aspergillus parasiticus, Trichoderma reesei, Candida albicans, Curvularia lunata, Geotricum candidum, Pyricularia oryzae, Helminthosporium oryzae, Rhizoctonia bataticola, Alternata alternate, Pythium aphanidermatum, Fusarium solani, and Sclerotium folfsi, Saccharomyces cerevisiae, parasites such as Leishmania chagasi, parasitic worm embryos, Plasmodium, Toxoplasma, and Theileria, phytoparasitic nematodes, viruses such as HIV-1, HSV-1 and HSV-2, Parainfluenza virus, Tobacco mosaic virus, Norovirus, Flavivirus, Avian influenza virus (H5N1). Moreover, compounds 1, 3, 4, 5, 6, 9, 10, 12, 14, 15, 16, 19, 23, $24,25,27,28,29,31$, and 35 were shown to possess anti-tumour activities against ovarian, hepatic, lung, prostate, nasopharyngeal, colon, skin, and vincristine resistant nasopharyngeal, breast cancer, as well as in the treatment of metabolic disorders, inflammation, diabetes, neurodegenerative diseases, convulsing disease, platelet-related disease conditions.

Out of 19 compounds identified in haemolymph water lysates, 5 were shown to possess biological activities including, Cpd2: 3,6-Dimethylbenzofuran-4-ol , Cpd3: 6,7-dimethoxy-1- 
methoxymethyl-3,4-dihydroisoquinoline, Cpd5: 3-Phthalimidopropionaldehyde , Cpd17: 3-ethyl5-phenylimidazolidine-2,4-dione, and Cpd19: Cholestane,3,5-dichloro-6-nitro-

(3beta,5alpha,6beta) (Table 2). For homologous searches, all compounds except Cpd7: N-Benzyl (4-Phenyl-3-propyl-1-oxaspiri[4,5]dec-3-enylidene) amine, possess reported biological activities (Table 2). For methanol-extracted haemolymph lysates, 18 compounds were identified and 5 of them were shown to possess biological activities including, Cpd21: 2-Ethyl-2-methoxypentanoic acid, Cpd23: 7-(Isopropoxy)-2,2,5-trimethylchromene, Cpd29: 5-methyl-2-(thiophen-2-

yl)pyridine, Cpd34: 2-Hydroxy-2-methylhexanoic acid, Cpd36: 2,7,12,17-tetraethyl-3,8,13,18tetramethyl-21H,23H-Porphine Copper (Table 2).

When compared with compounds extracted from muscles lysates with no antibacterial activity, out of a total of 20 compounds identified from cockroach brain lysates, 5 of them were found to be common in muscles lysates and brain lysates, indicating that possibly these were the compounds which are not responsible for the tested biological activities. However, the remaining 15 compounds were absent in the brain lysates and these included, i.e. Cpd 2:

(3S,6S,6aS,8S,10S,11aR,12R,12aS,13S)-1-ethyl-8,10,13-trimethoxy-3(methoxymethyl)tetradecahydro-1H-3,6a,12-(epiethane[1,1,2]triyl)-7,9-methanonaphtho[2,3b]azocine-6,11a,12-triol, Cpd 3: 3,6-Dimethylbenzofuran-4(5H)-ol, Cpd 4: 3-((6-methoxy1,2,3,4-tetrahydroisoquinolin-1-yl)methyl)phenol, Cpd 5: 4-benzyl-4,5-dihydroisoxazole, Cpd6: 6a-hydroxy-4-methoxy-6a,6b,7,8,9,10,10a,10b-octahydro-6H-benzo[3,4]cyclobuta[1,2c]chromen-6-one, Cpd 9: 2,2,4,7a-tetramethyl-6-(phenylsulfonyl)-3a,4,5,7atetrahydrobenzo[d][1,3]dioxole, Cpd 10: 3-(2'-Phenylethyl)-2,3-dihydro-6-phenyl-2,4-dioxo-4H1,3-thiazine, Cpd 11: 2-Amino-3,6-dimethylimidazo[4,5-b]pyridine, Cpd 12: 3,9-Dimethoxy12,13-dihydro-5H-indolo[2,3-a]pyrrolo[3,4-c]carbazole-6-benzyl, Cpd 13: (S,S)-1,1- 
Bis(ethoxycarbonyl)-2,2-bis-p-tolylsulfinyl-1-ethanol, Cpd 14: 1-methyl-[14-(13)C]-9,12methanobenzo[h]pyridazino[1,2-b]phthalazine-7,14-dione, Cpd 15: allyl(2-nitro-1phenylethyl)sulfane, Cpd 17: KARAKOLIDINE, Cpd 18: 2-isopropoxy-5-phenyl-1,3,4oxadiazole and Cpd 19: 1-(4-hydroxybenzyl)-3,4-dihydroisoquinoline-6,7-diol. However, compounds $1,7,8,16$ and 20 are common in muscles indicated that might be these does not possess potent biological activities against MRSA and neuropathogenic E.coli K1.

\section{Discussion}

Infectious diseases remain one of the leading causes of death worldwide (WHO 2002). Antibiotic-resistant bacteria continue to rise at an alarming rate (Nordmann et al. 2007; Devasahayam et al. 2010). Most currently available antibacterial drugs were discovered between 1940 and 1980 using traditional approaches, which have now become saturated. Most of the newer antibacterial drugs have arisen from chemical modification of existing antibiotic structures. Efforts to create new drugs using existing antibiotic scaffolds are challenging because these semi-synthetic derivatives are often not able to penetrate the bacterial cell wall adequately. More innovative, non-traditional strategies are therefore required in order to provide the urgently needed next generation of antimicrobial drugs. Insects represent a plentiful and untapped potential source of new antimicrobial drugs prompting us to investigate the antibacterial activity of their various tissues. The tissues of living multicellular organisms are potentially a rich source of nutrients for microbes and effective strategies have to be developed by the host organism to prevent microbial digestion. Cockroach lysates prepared from fat body and muscle tissue showed no antibacterial activity against bacteria tested in this study. This is in contrast to previous 
studies, which showed that insect such as Drosophila fat body produce seven distinct antimicrobial peptides, which are then secreted into the haemolymph to participate in a systemic response to septic injuries (Clynen and Schoots 2009; Metz-Boutigue et al. 2003; Amiche et al. 1999; Salzet 2001). However, this response is mounted as a result of microbial challenge. Since cockroaches used in our study were not immune-stimulated, prior to dissection, this could explain why no antibacterial activity was seen in fat and muscle tissues, while limited activity was observed in the haemolymph. Future work will involve immune stimulation of the cockroach, prior to dissection, by injecting heat-killed bacteria into the haemocoel to investigate if an inducible antibacterial effect can be detected. In contrast, cockroach brain lysates exhibited high antibacterial activity against bacteria tested in the present study. Furthermore, high antibacterial activity was observed at micro-level, showing high potency of the active component(s), which is presumably present at even lower amounts. Moreover, antibacterial molecule(s) were less than $10 \mathrm{kDa}$ in molecular mass, and non-toxic to human cells.

Using LC-MS, spectra was acquired from brain, haemolymph and muscles lysates. Out of hundreds of compounds, only few homologous compounds were identified (Table 1,2 and 3). The identified compounds possess characteristics in their structure like arrangement of specific functional groups and presence of active components, which makes them biologically significant for their potential therapeutic value against various infectious and non-infectious diseases. For example, several compounds in the brain lysates and haemolymph possess isoquinoline group, chromene derivatives, thiazine groups, imidazoles, pyrrole containing analogs, and are biologically active against broad-spectrum microorganisms, such as bacteria, fungi, viruses, parasites, and known to exhibit anti-tumour and anti-diabetic properties (Ali and El-Kazak 2010; Iwasa et al. 2001; Khafagy et al. 2002; Vennerstrom et al. 1995; Ozkay et al. 2010; Facchinetti et 
al. 2012; Bhardwaj et al. 2015). Similarly, sulfonamides and furanones are found to possess active components to treat many tumours, possess broad-spectrum antimicrobial activities, antiinflammatory and analgesic properties (Ozbek et al. 2007; He et al. 2015; Rappai et al. 2009). Other compounds contained flavanones. Flavanones are naturally occurring compounds present in fruits and vegetables and have considerable therapeutic potential in platelet inhibition, antibacterial, anti-tumour, antioxidant properties (Cushnie and Lamb 2005).

Notably, the majority of compounds in this study remain unidentified and/or whose biological activities have not yet been reported. It is hoped that chemical identities of all compounds and in vitro testing for their antibacterial, anti-tumour, antioxidant, anti-diabetic will determine their value for potential clinical applications. Although a detailed characterization of all compounds is needed, the present study suggest the potential significance of these naturally occurring compounds derived from novel sources, i.e., species living in challenging environments, can be a useful resource. To this end, insects such as cockroaches are potentially an important source of therapeutic molecules, as they share several environmental niches with humans and animals. This is evident from our findings that cockroach brain lysates possess potent antibacterial properties. Compared to vertebrates, the insects' nervous system is far more de-centralized. Behaviour such as feeding, movement and mating is controlled by segmental ganglia running the length of the insects' body, instead of the brain. In some cases, the brain may stimulate or inhibit activity in the segmental ganglia. The neuronal cells of the brain synthesize neurotransmitter and neuropeptide chemical messengers to communicate with each other and with peripheral organs (Clynen and Schoots 2009; Metz-Boutigue et al. 2003; Amiche et al. 1999; Salzet 2001). These chemical messengers represent the highest physiological hierarchy in animals controlling many crucial biological processes. It is therefore essential to the survival of 
the organism that this system is constantly protected against challenge from pathogens or noxious agents. Constitutive expression of antibacterial factors could provide this protection as a first line of defense before an inducible response has had time to manifest. In addition to metabolites that may possess antibacterial activity and/or inflammatory mediators, large neuropeptide precursor molecules such as proenkephalin and prodermaseptin, are known to be processed into smaller peptides, some of which have antibacterial activity (Clynen and Schoots 2009; Metz-Boutigue et al. 2003). The antimicrobial peptides have diverse amino acid sequences and structures but most are small amphipathic, cationic peptides that exert their antimicrobial effect by disrupting the structural integrity of cell membranes.

In conclusion, these findings suggest that compounds present in cockroach brains are of potential therapeutic value. Further identification, characterization and functional studies in vitro and in vivo using individual compounds can act as a breakthrough in developing novel therapeutics against various pathogens including superbugs. It is hoped that these molecules could eventually be developed into treatments for bacterial infections that are increasingly resistant to presently available drugs, however, this will require intensive research over the next few years.

\section{Compliance with Ethical Standards}

This article does not contain any studies with human participants or animals performed by any of the authors.

Funding: This study was funded by the FRGS, Malaysia, as well as the Higher Education Commission, Pakistan.

Conflict of Interest: Authors declares that they have no conflict of interest. 


\section{References}

Ajani OO, Familoni OB, Echeme JO, Wu F, Zheng S (2013) Synthesis and antibacterial activity of N,N-diethyl amide bearing benzenesulfonamide derivatives. Am Chem Sci J 3: 34-49

Akhter M, Akhter N, Alam MM, Zaman MS, Saha R, Kumar A (2011) Synthesis and biological evaluation of 2, 5-disubstituted 1, 3, 4-oxadiazole derivatives with both COX and LOX inhibitory activity. J Enzy Inhibit Med Chem 26:767-76

Alam MM, Husain A, Hasan SM, Anwer T (2009) Synthesis and pharmacological evaluation of $2(3 \mathrm{H})$-furanones and $2(3 \mathrm{H})$-pyrrolones, combining analgesic and anti-inflammatory properties with reduced gastrointestinal toxicity and lipid peroxidation. Eur J Med Chem 44: 2636-42

Alanazi AM, El-Azab AS, Al-Suwaidan IA, ElTahir KEH, Asiri YA, Abdel-Aziz NI, Alaa AM (2015) Structure-based design of phthalimide derivatives as potential cyclooxygenase-2 (COX-2) inhibitors: Anti-inflammatory and analgesic activities. Eur J Med Chem 92: 11523

Alanis AJ (2005) Resistance to antibiotics: are we in the post-antibiotic era? Arch Med Res 36: 697-705

Ali TES, El-Kazak AM (2010) Synthesis and antimicrobial activity of some new 1, 3-thiazoles, 1,3, 4-thiadiazoles, 1, 2, 4-triazoles and 1, 3-thiazines incorporating acridine and 1, 2, 3, 4tetrahydroacridine moieties. Eur J Chem 1: 6-11

Alisi MA, Cazzolla N, Furlotti G, Guglielmotti A, Polenzani L (2010) U.S. Patent No. 7,662,836. Washington, DC: U.S. Patent and Trademark Office 
Alisi MA, Cazzolla N, Garofalo B, Furlotti G, Ombrato R, Mancini F (2013) U.S. Patent Application 14/373,393

Anthony NG, Breen D, Clarke J, Donoghue G, Drummond AJ, Ellis EM, Gemmell CG, Helesbeux JJ, Hunter IS, Khalaf AI, Mackay SP (2007) Antimicrobial lexitropsins containing amide, amidine, and alkene linking groups. J Med Chem 50(24): 6116-25

al-Rashida M, Ejaz SA, Ali S, Shaukat A, Hamayoun M, Ahmed M, Iqbal J (2015)

Diarylsulfonamides and their bioisosteres as dual inhibitors of alkaline phosphatase and carbonic anhydrase: Structure activity relationship and molecular modelling studies. Bioorg Med Chem 23: 2435-44

Altmeyer R, Sharma G, Pendharkar VV, Sharma DC (2010) U.S. Patent Application 12/855,046

Alvarez FN, Carlson LM, Lindner I, Lee KP (2009) 6, 7-Dihydroxy-3, 4-dihydroisoquinoline: A novel inhibitor of nuclear factor- $\kappa \mathrm{B}$ and in vitro invasion in murine mammary cancer cells. Chemother 55:175-82

Amiche M, Seon AA, Pierre TN, Nicolas P. (1999) The dermaseptin precursors: a protein family with a common preproregion and a variable C-terminal antimicrobial domain. FEBS Lett 456: $352-6$

Amutha C, Saravanan S, Muthusubramanian S (2014) Synthesis and antioxidant characteristic of novel thiazolidinone derivatives. Ind J Chem 53: 377-83

Antoniou S (2015) Rivaroxaban for the treatment and prevention of thromboembolic disease. J Pharm Pharmacol 67: 1119-32 
Antonucci T, Warmus JS, Hodges JC, Nickell DG (1995) Characterization of the antiviral activity of highly substituted pyrroles: a novel class of non-nucleoside HIV-1 reverse transcriptase inhibitor. Anti Chem Chemother 6: 98-108

Armati P, Gilmour D (1976) Monoamines in the nervous system of the Queensland fruit fly, Dacus tryoni. Aus J Entomol 15: 79-84

Arrowood MJ, Sterling CR (1989) Comparison of conventional staining methods and monoclonal antibody-based methods for Cryptosporidium oocyst detection. J Clin Microbiol 27: 1490-5

Aslanian RG, Chan TY, Harris JM, McKittrick BA, Neustadt BR, Palani A (2008) Preparation of spirocyclic azetidinone derivatives and therapeutic applications thereof. PCT Int. Appl. WO 2008033465 A1 20080320

Aziz-ur-Rehman Abbasi MA, Rasool S, Ashraf M, Ejaz SA, Hassan R (2014) Synthesis, spectral characterization and enzyme inhibition studies of different chlorinated sulfonamides. Pak $\mathbf{J}$ Pharm Sci 27: 1739-45

Bachi MD, Korshin EE, Ploypradith P, Cumming JN, Xie S, Shapiro TA, Posner GH (1998) Synthesis and in vitro antimalarial activity of sulfone endoperoxides. Bioorg Med Chem Lett 8: 903-8

Bajpai VK, Sharma A, Moon B, Baek KH (2014) Chemical Composition Analysis and Antibacterial Mode of Action of Taxus Cuspidata Leaf Essential Oil against Foodborne Pathogens. J Food Safe 34: 9-20 
Bang SC, Kim Y, Yun MY, Ahn BZ (2004) 5-Arylidene-2 (5H)-furanone derivatives: synthesis and structure-activity relationship for cytotoxicity. Arch Pharm Res 27: 485-94

Basak SC, Mills D, Hawkins DM, Bhattacharjee AK (2010) Quantitative structure-activity relationship studies of antimalarial compounds from their calculated mathematical descriptors. Sar Qsar Environ Res 21(1-2): 103-125

Bauman JD, Das K, Patel D, Arnold E (2014) U.S. Patent No. 8,859,290. Washington, DC: U.S. Patent and Trademark Office

Bauquier JR, Tudor E, Bailey SR (2015) Anti-inflammatory effects of four potential anti-endotoxaemic drugs assessed in vitro using equine whole blood assays. J Vet Pharmacol Ther 38(3): 290-296

Bettsworth F, Martinez J (2015) Use of carboxylic acids to stabilize aqueous solution of glutamate dehydrogenase. PCT Int. Appl. WO 2015086973 A1 20150618

Bhardwaj V, Gumber D, Abbot V, Dhiman S, Sharma P (2015) Pyrrole: a resourceful small molecule in key medicinal hetero-aromatics. RSC Advance 5: 15233-66

Bierer D, Johnson J, Ladouceur G, Scott W, McClure A, Fu W, Achebe F, Burke M, Bi C, Hart B (2002) 3-pyridyl or 4-isoquinolinyl thiazoles as c17, 20 lyase inhibitors. U.S. Patent Application 10/490,822

Bilich BE, Vladimirtsev IF, Cherkasov VM, Khripko SS (1970) Search for antimicrobic substances of antibioticlike action among some b-nitrostyrene derivatives. Antibioti (Kiev) 5: $31-6$ 
Bondock S, Naser T, Ammar YA (2013) Synthesis of some new 2-(3-pyridyl)-4, 5-disubstituted thiazoles as potent antimicrobial agents. Eur J Med Chem 62: 270-9

Bonnett R (1995) Photosensitizers of the porphyrin and phthalocyanine series for photodynamic therapy. Chem Soc Rev 24: 19-33

Bonnett R, Martınez G (2001) Photobleaching of sensitisers used in photodynamic therapy. Tetrahedron 57(47): 9513-9547

Braud E, Goddard ML, Kolb S, Brun MP, Mondésert O, Quaranta M, Gresh N, Ducommun B, Garbay C (2008) Novel naphthoquinone and quinolinedione inhibitors of CDC25 phosphatase activity with antiproliferative properties. Bioorg Med Chem 16(19): 9040-9

Breton G, Lozachmeur S, Lennon B (2015) Antioxidant composition intended for oxidative stabilization of marine, animal, or plant oils. Fr. Demande FR 3012292 A1 20150501

Brown BE, Starratt AN (1975) Isolation of proctolin, a myotropic peptide, from Periplaneta americana. J Insect Physiol 21: 1879-81

Brüning A, Kimmich T, Brem GJ, Buchholtz ML, Mylonas I, Kost B, Gingelmaier A (2014) Analysis of endoplasmic reticulum stress in placentas of HIV-infected women treated with protease inhibitors. Reproduc Toxicol 50: 122-8

Brunskole Švegelj M, Turk S, Brus B, Lanišnik Rižner T, Stojan J, Gobec S (2011) Novel inhibitors of trihydroxynaphthalene reductase with antifungal activity identified by ligandbased and structure-based virtual screening. J Chem Info Mod 51: 1716-24 
Bulet P, Hetru C, Dimarcq JL, Hoffmann D (1999) Antimicrobial peptides in insects; structure and function. Develop Compar Immunol 23: 329-44

Bur D, Grisostomi C, Nayler O, Remen L, Vercauteren M, Welford R (2015) Preparation of tricyclic piperidine compounds, particularly thiadiazoloimidazopyridines, thiazoloimidazopyridines and derivatives, as inhibitors of tryptophan hydroxylase. PCT Int. Appl. WO 2015075023 A1 20150528

Burke TR, Fesen M, Mazumder A, Yung J, Wang J, Carothers AM, Grunberger D, Driscoll J, Pommier Y, Kohn K (1995) Hydroxylated aromatic inhibitors of HIV-1 integrase. J Med Chem 38(21): 4171-8

Capitosti SM, Hansen TP, Brown ML (2004) Thalidomide analogues demonstrate dual inhibition of both angiogenesis and prostate cancer. Bioorg Med Chem 12: 327-36

Carvalho AM, Miranda AM, Santos FA, Loureiro APM, Fisberg RM, Marchioni DM (2015) High intake of heterocyclic amines from meat is associated with oxidative stress. Br J Nutr 113: $1301-7$

Celikler S, Tas S, Ziyanok-Ayvalik S, Vatan O, Yildiz G, Ozel M (2014) Protective and antigenotoxic effect of Ulva Rigida C. Agardh in experimental hypothyroid. Acta Biol Hung 65: 13-26

Cesarini S, Spallarossa A, Ranise A, Schenone S, Rosano C, La Colla P, Sanna G, Busonera B, Loddo R (2009) N-Acylated and N, N'-diacylated imidazolidine-2-thione derivatives and $\mathrm{N}, \mathrm{N}^{\prime}$-diacylated tetrahydropyrimidine-2 (1H)-thione analogues: Synthesis and antiproliferative activity. Eur J Med Chem 44(3): 1106-18 
Chansukh K, Palanuvej C, Ruangrungsi N (2014) Antibacterial activities of selected Thai medicinal plants bearing quinonoids. 425-432

Chen HY, Chen XY (2012) Effect of peimine on inhibiting the MCF-7/TAM proliferation of human breast cancer cell and its influence on cell apoptosis. Zhong Xueb 40: 12-5

Chen P, Horton LB, Mikulski RL, Deng L, Sundriyal S, Palzkill T, Song Y (2012) 2-Substituted 4, 5-dihydrothiazole-4-carboxylic acids are novel inhibitors of metallo- $\beta$-lactamases. Bioorg Med Chem Lett 22: 6229-32

Chen YC (2013) Methods for treating neurodegenerative diseases associated with aggregation of amyloid-beta. U.S. Patent Application No. 14/109,948

Cheng H, Cong Q, Gangwar S, Zhang Q (2011) Antiproliferative compounds structurally related to tubulysins, conjugates thereof for targeted delivery, methods of preparation, and uses thereof. U.S. Pat. Appl. Publ. US 20110027274 A1 20110203

Chikhale H, Lade K, Joshi P, Kudale S, Nerkar A, Sawant S (2012) In silico design, synthesis \& pharmacological screening of some quinazolinones as possible gabaa receptor agonists for anticonvulsant activity. Int J Pharm Pharmac Sci 4: 466-69

Chung YS, Siu ML, Lai TH, Yeh SC (2013) U.S. Patent Application 14/144,264

Clynen E, Schoots L (2009) Peptidomic survey of the locust neuroendocrine system. Insect. Biochem. Mol Biol 39: 491-507

Combourieu B, Besse P, Sancelme M, Godin JP, Monteil A, Veschambre H, Delort, AM (2000) Common Degradative Pathways of Morpholine, Thiomorpholine, and Piperidine by 
Mycobacterium aurum MO1: Evidence from1H-Nuclear Magnetic Resonance and Ionspray Mass Spectrometry Performed Directly on the Incubation Medium. Appl Environ Microbiol 66(8): 3187-3193

Correa AG, Baraldi PT, Soares AM (2008) U.S. Patent Application 12/602,347

Cushnie TT, Lamb AJ (2005) Antimicrobial activity of flavonoids. Int J Antimicrob Agents 26: $343-56$

Dai Y, Pochapsky TC, Abeles RH (2001) Mechanistic studies of two dioxygenases in the methionine salvage pathway of Klebsiella pneumoniae. Biochem 40: 6379-87

Danishefsky SJ, Chou TC, Lei X, Yun H, Ng F, Hartung J, Sames D (2014) Preparation of panaxytriol derivatives useful for reducing toxicity and treating or preventing diseases.

U.S. US 8859615 B2 20141014

De S, Dey A, Aneela S (2013) GC-MS analysis of phytocomponents in the methanolic extract of Oldenlandia umbellate. 4: 29-32

De Simone R, Andrés RM, Aquino M, Bruno I, Guerrero MD, Terencio MC, Paya M, Riccio R (2010) Toward the Discovery of New Agents Able to Inhibit the Expression of Microsomal Prostaglandin E Synthase-1 Enzyme as Promising Tools in Drug Development. Chem Biol Drug Des 76(1): 17-24

De Troconis MIC, De Aulacio MP, De TC (2000) Molecular modeling and antibacterial activitystructure relationships of nalidixic acid quinolin anlogs. Bol Soc Chil Quim 45(1): 5-13

Dente EL (2014) U.S. Patent Application 14/560,776 
Deprez P, Mandine E, Gofflo D, Meunier S, Lesuisse D (2002) Small ligands interacting with the phosphotyrosine binding pocket of the Src SH 2 protein. Bioorg Med Chem Lett 12: $1295-8$

Desplaces N, Gutmann L, Carlet J, Guibert J, Acar JF (1986) The new quinolones and their combinations with other agents for therapy of severe infections. J Antimicrob Chemother 17(suppl A): 25-39

Devasahayam G, Scheld WM, Hoffman PS (2010) Newer antibacterial drugs for a new century. Expert Opin Investig Drugs 19: 215-34

Di Marzo V, De Petrocellis L, Moriello AS (2008) U.S. Patent Application 12/596,500

Dubost C, Vors JP, Coqueron PY (2013) Preparation of 1-methyl-3-dihalomethyl-5halopyrazole(thio)indanylcarboxamide derivatives as fungicides useful in. PCT Int. Appl. WO 2013167544 A1 20131114

Duś D, Wojdat E, Radzikowski C, Mastalerz P (1984) Cytostatic activity in vitro of phosphonic acid derivatives. Arch Immunol Ther Exp 33: 325-9

Eddington ND, Cox DS, Roberts RR, Butcher RJ, Edafiogho IO, Stables JP, Cooke N, Goodwin AM, Smith CA, Scott KR (2002) Synthesis and anticonvulsant activity of enaminones.: 4. Investigations on isoxazole derivatives. Eur J Med Chem 37(8): 635-48

Ellendorff T, Brun R, Kaiser M, Sendker J, Schmidt TJ (2015) PLS-Prediction and Confirmation of Hydrojuglone Glucoside as the Antitrypanosomal Constituent of Juglans Spp. Molecules 20(6): 10082-10094 
Ellingboe JW, Nikaido M, Bagli J (1992) Preparation of pyridopyrimidinones and pyrrolopyrimidinones as angiotensin II antagonists. U.S. US 5149699 A 19920922

Elliott S, Evans J (2014) A 3-year review of new psychoactive substances in casework. Foren Sci Int 243: 55-60

Emran TB, Rahman MA, Uddin MMN, Dash R, Hossen MF, Mohiuddin M, Alam MR (2015) Molecular docking and inhibition studies on the interactions of Bacopa monnieri's potent phytochemicals against pathogenic Staphylococcus aureus. Daru 23(1): 26

Engelsma G, Yamamoto A, Markham E, Calvin M (1962) The effect of light on oxidation and reduction reactions involving phthalocyanine and etioporphyrin I manganese complexes. J Phy Chem 66: 2517-31

Enright MC (2003) The evolution of a resistant pathogen--the case of MRSA. Curr Opin Pharmacol 3:474-9

Exarchou V, Kanetis L, Charalambous Z, Apers S, Pieters L, Gekas V, Goulas V (2015) HPLCSPE-NMR characterization of major metabolites in Salvia fruticosa Mill. Extract with antifungal potential: Relevance of carnosic acid, carnosol, and hispidulin. J Agri Food Chem 63: 457-63

Facchinetti V, Reis da RR, Gomes RBC, Vasconcelos RAT (2012) Chemistry and biological activities of 1, 3-benzothiazoles. Mini Rev Org Chem 9: 44-53

Fang Y, Feng Y, Li M (2008) Optimal QSAR analysis of the carcinogenic activity of aromatic and heteroaromatic amines. QSAR Combin Sci 27: 543-54 
Flefel EM, Tantawy WA, Abdel-Mageid RE, Amr AEGE, Nadeem R (2014) Synthesis and antiviral activities of some 3-(naphthalen-1-ylmethylene)-5-phenylfuran-2 (3H)-one candidates. Res Chem Intermed 40: 1365-81

Flentge CA, Chen HJ, Degoey DA, Flosi WJ, Grampovnik DJ, Huang PP (2011) Preparation of sulfonylaminobutanamide derivatives for use as HIV protease inhibitors. U.S. Pat. Appl. Publ. US 20110003827 A1 20110106

Fodor A, Tímár T, Kiss I, Hosztafi S, Varga É, Soos J, Sebök P (1989) Effects of precocene analogs on the nematode Caenorhabditis remanei (var. bangaloreiensis): I. Structure/activity relations. Gen Comp Endocrinol 74: 18-31

Frederico MJ, Mascarello A, Castro AJ, Mendes CP, Kappel VD, Cazarolli LH (2013) Antidiabetic effects of sulfonamide derivatives based on structural fragment of sulfonylureas. Curr Trend Med Chem 7: 11-25

Fu QC, Liu C, Wang Y, Li CH, Hu Q (2015) Germination inhibitors of Sinojackia sarcocarpa L. Q. Luo drupe methanol extract. Beif Yuan 2: 6-9

Fung CYE, Fung KP, Mahaut-Smith M (2008) 5-Methyl-6, 7-dihydro-5H-cyclopentapyrazine for use in therapy, especially treating platelet-related diseases such as thrombosis, and as a male contraceptive. GB2439923

Funk P, Motyka K, Dzubak P, Znojek P, Gurska S, Kusz J, Soural M (2015) Preparation of 2Phenyl-3-hydroxyquinoline-4 (1H)-one-5-carboxamides as Potential Anticancer and Fluorescence Agents. RSC Adv 5: 48861-7 
Ganguli S, Firdous M, Maity TS, Bera RK, Panigrahi M (2012) The study of antihyperlipidemic activities of schiff bases of $4(3 \mathrm{H})$ quinazolinone derivatives in rats. Int J Pharm Pharmaceut Sci 4: 175-8

Ganguly S, Murugesan S 3D QSAR-Comparative Molecular Similarity Indices Analysis of 2Heteroarylquinoline-4-amines as Possible Anti-HIV-1 Agents.

Gao XJ, Wang TC, Zhang ZC, Cao YG, Zhang NS, Guo MY (2015) Brazilin plays an antiinflammatory role with regulating Toll-like receptor 2 and TLR 2 downstream pathways in Staphylococcus aureus-induced mastitis in mice. Int Immunopharmacol 27: 130-7

George S, Nair SA, Venkataraman R, Baby S (2015) Chemical composition, antibacterial and anticancer activities of volatile oil of Melicope denhamii leaves. Nat Prod Res 29: 1959-62

Ghattas AEBA, Moustafa HM, Hassanein EA, Hussein BR (2012) Synthesis and antibacterial activity of some new 4-anilino-5-phenyl-4H-1, 2, 4-triazole-3-thiol derivatives. Arabian J Chem

Giller SA, Dubur GY, Zilber JA, Bljuger AF, Zarinya LA, Maiore AY (1976) Pharmaceutical composition for treating liver diseases. Brit. GB 1426499 A 19760225

Ginsborg BL, Turnbull KW, House CR (1976) On the actions of compounds related to dopamine at a neurosecretory synapse. Br J Pharmacol 57: 133-40

Girard Y, Yoakim-Rancourt C, Hamel P, Gillard JW, Guindon Y, Letts G, Lord A (1989) Tetrahydrocarbazol-1-acetic acids: new class of thromboxane receptor antagonists. Prog Clin Biol Res 301: 585 
Givskov M, Yang L, Tan YY (2014) Quorum sensing inhibitors and uses thereof as antibacterial agents. PCT Int. Appl. WO 2014142748 A1 20140918

Gökce M, Özcelik B, Akyon Y, Berçin E, Noyanalpan N (2004) Activity of 1-[(2-aminophenyl) thio]-1-phenyl-2-nitroalkane derivatives against Helicobacter pylori. Turk J Pharm Sci 1: $55-64$

Gómez CMM, Kouznetsov VV, Sortino MA, Álvarez SL, Zacchino SA (2008) In vitro antifungal activity of polyfunctionalized 2-(hetero) arylquinolines prepared through imino Diels-Alder reactions. Bioorg Med Chem 16: 7908-20

Gonewar NR, Jadhav VB, Killedar AA, Sakure SS, Jadhav KD, Sarawadekar RG (2012) Synthesis, characterization and antimicrobial activities of 1,2 naphthoquinone-1-oxime ligand and its metal chelates of. Int J Chem Sci 10: 1493-505

Gonzalez Perez JA, Estevez Braun A, Gutierrez Ravelo A, Estevez Reyes R (1995) Phenyl compounds for the control of phytoparasitic nematodes. PCT Int. Appl. WO 9515082 A1 19950608

Griggs AM, Agim ZS, Mishra VR, Tambe MA, Director-Myska AE, Turteltaub KW, Cannon JR (2014) 2-Amino-1-methyl-6-phenylimidazo [4, 5-b] pyridine (PhIP) is selectively toxic to primary dopaminergic neurons in vitro. Toxicol Sci 140: 179-89

Groves RL, Chapman S, Lowenstein DM, Huseth AS, Groves CL (2012) Registeted and experimental foliar insecticides to control colorado potato beetle and potato leafhopper in potato, 2011. Arthropod Management Tests 37(1): E47 
Grueneberg DA, Kalid O, Xian J, Rajur SB, Kim HO, Neelagiri VR (2014) Novel methods, compounds, and compositions for inhibition of ROS kinase. PCT Int. Appl. WO 2014141129 A2 20140918

Guzman JD, Pesnot T, Barrera DA, Davies HM, McMahon E, Evangelopoulos D, Angell R (2015) Tetrahydroisoquinolines affect the whole-cell phenotype of Mycobacterium tuberculosis by inhibiting the ATP-dependent MurE ligase. J Antimicrob Chem 70: 1691703

Guzzi U, Ciabatti R, Padova G, Battaglia F, Cellentani M, Depaoli A, Spina G (1986) Structureactivity studies of 16-methoxy-16-methyl prostaglandins. J Med Chem 29: 1826-32

Győrfi J, Geösel A, Kiss M, Nemes K, Csóka M, Korány K (2013) Gas Chromatography-Mass Spectrometry Confirmation of the Sensory Scent Features of the Most Commonly Consumed Agaricus bisporus and Agaricus subrufescens Exhibiting Anticancerous Traits. J Med Food 16: 167-75

Hamdy A, Rothbaum W, Izumi R, Lannutti B, Covey T, Ulrich R (2015) Therapeutic combination of a phosphoinositide 3-kinase (PI3K) inhibitor and a Bruton's tyrosine kinase (BTK) inhibitor for treating hyperproliferative disorders such as cancer. PCT Int. Appl. WO 2015083008 A1 20150611

Han J, Tan P, Li Z, Wu Y, Li C, Wang Y, Liu Y (2014) Fuzi attenuates diabetic neuropathy in rats and protects Schwann cells from apoptosis induced by high glucose. PloS one 9(1): e86539 
Hanauske-Abel HM, Palumbo P, Cracchiolo BM, Park MH, Wolff EC, Hanauske AR (2005) Method using ciclopirox and other heterocyclic compounds for preventing survival of retrovirally infected cells and of inhibiting formation of infectious retroviruses. PCT Int. Appl. WO 2005055931 A2 20050623

Harada K, Matsushita A, Kawachi Y, Sasaki H (1996) Preparation of b-ketophosphonate derivatives as anticholesteremic intermediates. Jpn Kok Tok Koho JP 08099982 A 19960416

Hardick DJ, Blagbrough IS, Cooper G, Potter BV, Critchley T, Wonnacott S (1996) Nudicauline and elatine as potent norditerpenoid ligands at rat neuronal $\alpha$-bungarotoxin binding sites: Importance of the 2-(methylsuccinimido) benzoyl moiety for neuronal nicotinic acetylcholine receptor binding. J Med Chem 39: 4860-6

Hatano H, Takekawa F, Hashimoto K, Ishihara M, Kawase M, Qing C, Sakagami H (2009) Tumor-specific cytotoxic activity of 1,2, 3, 4-tetrahydroisoquinoline derivatives against human oral squamous cell carcinoma cell lines. Anticancer Res 29: 3079-86

Hatch FT, Knize MG, Colvin ME (2001) Extended quantitative structure-activity relationships for 80 aromatic and heterocyclic amines: structural, electronic, and hydropathic factors affecting mutagenic potency. Environ Mol Mutagen 38: 268-91

He W, Xue C (2014) Effects of rosuvastatin on left ventricular diastolic function in older patients with hypertension. Xinfei Xueguan Zazhi 33: 699-701 
He X, Du X, Zang X, Dong L, Gu Z, Cao L, Guan X (2015) Extraction, identification and antimicrobial activity of a new furanone, grifolaone A, from Grifola frondosa. Nat Prod Res 30: 941-7

Heffernan ML, Fang QK, Foglesong RJ, Hopkins SC, Ogbu CO, Soukri M (2011) Preparation of fused pyrrole derivatives as inhibitors of D-amino acid oxidase. PCT Int. Appl. WO 2011011330 A2 20110127

Huang LJ, Ge YH, Liu KX, Zhang JX, Hao XJ (2013) Chemical constituents from Aconitum recemulosum and their effects against TMV. Nongyao 52: 295-7

Huchel U, Materne M, Levert I, Smyrek H, Bunn R, Rittler F (2015) Use of CNGA2 agonists for enhancing the olfactory effect of an odorant. Ger Offen DE 102013226602 A1 20150625

Huegin A (2012) 1,4-Naphthoquinones for treating pox virus infections. PCT Int. Appl. WO 2012052956 A1 20120426

Hung KS (2015) Use of indolyl and indolinyl hydroxamates for treating neurodegenerative disorders or cognitive deficits. PCT Int. Appl. WO 2015077685 A1 20150528

Husain A, Hasan SM, Lal S, Alam MM (2006) Antibacterial and antifungal activities of 2arylidene-4-(4-methylphenyl) but-3-en-4-olides and their pyrrolone derivatives. Ind J Pharmaceut Sci 68: 536

Hussain H, Kock I, Al-Harrasi A, Abbas G, Green IR, Draeger S, Krohn K (2014) Anti microbial and phytochemical investigation of the endophytic fungus Acremonium sp. J Herb Med 3: $1-4$ 
Idhayadhulla A, Kumar RS, Nasser AJA, Manilal A, Ismail IB, Al-Busadah KA, Ortiz GG (2013) Nurulisa Zulkifle. Int J Biol Chem 7: 15-26

Indumathi S, Karthikeyan R, Nasser A, Jamal A, Idhayadhulla A, Surendra Kumar R (2015) Anticonvulsant, analgesic and anti-inflammatory activities of some novel pyrrole and 1, 4dihydropyridine derivatives. J Chem Pharmaceut Res 7: 434-40

Ishikawa T, Watanabe T, Tanigawa H, Saito T, Kotake KI, Ohashi Y, Ishii H (1996) Nitrosation of phenolic substrates under mildly basic conditions: Selective preparation of p-quinone monooximes and their antiviral activities. J Org Chem 61: 2774-9

Istanbullu H, Erzurumlu Y, Kirmizibayrak PB, Erciyas E (2014) Evaluation of Alkylating and Intercalating Properties of Mannich Bases for Cytotoxic Activity. Lett Drug Desig Discov 11: $1096-6$

Iwaoka K, Imanishi N, Ito H, Miyata K, Ota M (1998) Pharmaceuticals containing 2phenylthiazoles as 5-HT3 receptor agonists, and preparation of the compounds. Jpn Kokai Tokkyo Koho JP 10017569 A 19980120

Iwasa K, Moriyasu M, Tachibana Y, Kim HS, Wataya Y, Wiegrebe W, Lee KH (2001) Simple isoquinoline and benzylisoquinoline alkaloids as potential antimicrobial, antimalarial, cytotoxic, and anti-HIV agents. Bioorg Med Chem 9: 2871-84

Jahangir M, Ilyas SA, Mazhar F, Abbasi MA, Usman MF, Rehman J, Ajaib M (2013) Antimicrobial and Antioxidant Potential of Astragalus psilocentros. Asia J Chem 25: 175

Jansen J, McBride C, Renhowe P, Shafer C (2005) U.S. Patent Application 11/261,995 
Johnson RA (1996) U.S. Patent No. 5,500,417. Washington, DC: U.S. Patent and Trademark Office

Kalopissis G, Manoussos G (1976) U.S. Patent No. 3,950,542. Washington, DC: U.S. Patent and Trademark Office

Kane VV, Levine SD (1981) U.S. Patent No. 4,250,180. Washington, DC: U.S. Patent and Trademark Office

Kaplan A, Gaschler MM, Dunn DE, Colligan R, Brown LM, Palmer AG, Stockwell BR (2015) Small molecule-induced oxidation of protein disulfide isomerase is neuroprotective. PNAS 112: E2245-E2252

Karakaya I, Karabuga S, Ulukanli Z, Ulukanli S (2013) Synthesis and antifungal evaluation of imines derived from 3-amino-2-isopropyl-3H-quinazoline-4-one. Org Commun 6: 139-47

Kasai S (2014) A novel Parkinson's disease drug, istradefylline. BIO Clin 29: 1301-7

Kasai S, Igawa H, Takahashi M, Maekawa T, Kakegawa K, Yasuma T (2013) Preparation of benzimidazole and imidazopyridine derivatives and analogs as $\mathrm{MCH}$ receptor antagonists for treating obesity. PCT Int. Appl. WO 2013105676 A1 20130718

Kawaminami E, Takahashi T, Kanayama T, Sakamoto K (2012) Preparation of heterocyclecarboxamide compounds as LPA receptor antagonists. PCT Int. Appl. WO 2012039460 A1 20120329

Khafagy MM, El-Wahab AHA, Eid FA, El-Agrody AM (2002) Synthesis of halogen derivatives of benzo [h] chromene and benzo [a] anthracene with promising antimicrobial activities. II Farmaco 57: 715-22 
Khan NA, Osman K, Goldsworthy G (2008) Lysates of Locusta migratoria brain exhibit potent broad spectrum antibacterial activity. J Antimicrob Chemother 62: 634-5

Khan NA, Siddiqui R (2009) Acanthamoeba affects the integrity of human brain microvascular endothelial cells and degrades the tight junction proteins. Int J Parasitol 39: 1611-6

Kim HD, Lee JM (2015) Perfume composition for masking odorous smell in formulation comprising amine. Repub Kor Kong Taeh Kong KR 2015070937 A 20150625

Kiyama R, Kanda Y, Tada Y, Fujishita T, Kawasuji T, Takechi S, Fuji M (2003) Preparation of heterocyclic compounds as integrase inhibiting antiviral agents. WO2003016275

Kon T, Kato S, Morie T, Harada H (1991) Preparation of indazole-3-carboxamidohexahydro1,4-diazepines as serotoninergic S3 antagonists. Jpn Kok Tok Koh JP 03223280 A 19911002

Kormann EC, de Aguiar Amaral P, David M, Eifler-Lima VL, Cechinel Filho V, de Campos Buzzi F (2012) Kavain analogues as potential analgesic agents. Pharmacol Rep 64(6): $1419-1426$

Korthout HA (2012) Medical use for acidic cannabinoids for increasing natural resistance in an animal or enhancing cellular resistance for use in therapy. PCT Int. Appl. WO 2012144892 A1 20121026

Kosakai H, Hirose A (2015) Ethanol-containing food preservative and food preservation method using it. Jpn Kok Tok Koh JP 2015123062 A 20150706

Kouznetsov VV, Vargas Mendez LY, Milena Leal S, Mora Cruz U, Andres Coronado C, Melendez Gomez CM, Escobar Rivero P (2007) Target-oriented synthesis of antiparasitic 
2-hetaryl substituted quinolines based on imino Diels-Alder reactions. Lett Drug Desig Discov 4: 293-6

Kouznetsov VV, Rojas Ruiz A, Vargas Mendez LY, Gupta M (2012) Simple C-2-substituted quinolines and their anticancer activity. Lett Drug Desig Discov 9: 680-6

Kumar P, Rawat A, Keshari AK, Singh AK, Maity S, De A, Saha S (2015) Antiproliferative effect of isolated isoquinoline alkaloid from Mucuna pruriens seeds in hepatic carcinoma cells. Nat Prod Res 30: 460-3

La J, Latham CF, Tinetti RN, Johnson A, Tyssen D, Huber KD, Tachedjian G (2015) Identification of mechanistically distinct inhibitors of HIV-1 reverse transcriptase through fragment screening. PNAS 112: 6979-84

Lack NA, Axerio-Cilies P, Tavassoli P, Han FQ, Chan KH, Feau C, Cherkasov A (2011) Targeting the binding function 3 (BF3) site of the human androgen receptor through virtual screening. J Med Chem 54: 8563-73

Le BV, Klöck C, Schatz A, Nguyen JB, Kakani EG, Catteruccia F, Baxter RH (2014) Dihydroisoxazole inhibitors of Anopheles gambiae seminal transglutaminase AgTG3. Malar J 13: 210

Leal KW, Troupin AS (1977) Clinical pharmacology of anti-epileptic drugs: a summary of current information. Clin Chem 23: 1964-8

Lee S, Duce I, Atkins H, Khan NA (2011) Cockroaches and locusts: physicians' answer to infectious diseases. Int J Antimicrob Agents 37: 279-80 
Levy SB, Alekshun MN, Podlogar BL, Ohemeng K, Verma AK, Warchol T, Bhatia B, Bowser T Grier M (2005) Substituted benzoimidazole compounds as transcription factor-modulating compounds useful as anti-infectives. US Patent Appl. 2005124678, pA120050609

Li H, Shinde PB, Lee HJ, Yoo ES, Lee CO, Hong J, Jung JH (2009) Bile acid derivatives from a sponge-associated bacterium Psychrobacter sp. Arch Pharm Res 32: 857-62

Lima TC, Santos ADC, Costa DT, Souza RJ, Barison A, Steindel M, Biavatti MW (2015) Chromenes from leaves of Calea pinnatifida and evaluation of their leishmanicidal activity. Rev Bras Farmaco 25: 7-10

Liou SF, Hsu JH, Chu HC, Lin HH, Chen IJ, Yeh JL (2015) KMUP-1 Promotes Osteoblast Differentiation Through cAMP and cGMP Pathways and Signaling of BMP-2/Smad1/5/8 and Wnt/ $\beta$-Catenin. J Cell Physiol 230: 2038-48

Liu G, Wu Y, Xu H, Liu H (2013) A Green Route for the Synthesis of Antiepileptic Drug Losigamone and Its Analogues. Chin J Org Chem 33(7): 1527-1539

Lujan SA, Guogas LM, Ragonese H, Matson SW, Redinbo MR (2007) Disrupting antibiotic resistance propagation by inhibiting the conjugative DNA relaxase. PNAS 104: 12282-7

Ma M, Feng J, Li R, Chen SW, Xu H (2015) Synthesis and antifungal activity of ethers, alcohols, and iodohydrin derivatives of sclareol against phytopathogenic fungi in vitro. Bioorg. Med Chem Lett 25(14): 2773-2777

Macias WL (2001) Compositions containing potential secretory phospholipase A2 (sPLA2) inhibitors for the treatment of pain. PCT Int. Appl. WO 2001066111 A1 20010913 
Macias WL, Meador VP (2001) Methods and formulations containing secretory phospholipase A2 (sPLA2) inhibitors for the treatment of renal dysfunction. PCT Int. Appl. WO 2001066110 A2 20010913

Mackmull MT, Iskar M, Parca L, Singer S, Bork P, Ori A, Beck M (2015) Histone Deacetylase Inhibitors (HDACi) Cause the Selective Depletion of Bromodomain Containing Proteins (BCPs). Mol Cell Proteo 14: 1350-60

Makowski CT, Rissmiller RW, Bullington WM (2015) Riociguat: A Novel New Drug for Treatment of Pulmonary Hypertension. Pharmacotherapy. J Hum Pharm Drug Ther 35: $502-19$

Mareddy J, Nallapati SB, Anireddy J, Devi YP, Mangamoori LN, Kapavarapu R, Pal S (2013) Synthesis and biological evaluation of nimesulide based new class of triazole derivatives as potential PDE4B inhibitors against cancer cells. Bioorg Med Chem Lett 23(24): 6721-6727

Mashhoon N, Pruss C, Carroll M, Johnson PH, Reich NO (2006) Selective inhibitors of bacterial DNA adenine methyltransferases. J Biomol Screen 11: 497-510

Mautino M, Jaipuri F, Marcinowicz-Flick A, Kesharwani T, Waldo J (2009) Preparation and disclosure of indoleamine 2,3-dioxygenase (IDO) inhibitors. PCT Int. Appl. WO 2009073620 A2 20090611

Mayhoub AS, Khaliq M, Botting C, Li Z, Kuhn RJ, Cushman M (2011) An investigation of phenylthiazole antiflaviviral agents. Bioorg Med Chem 19: 3845-54 
Mehetre D (2013) Synthesis and Evaluation of Antimicrobial activity of Gamma Butyrolactone. Int J Pharmaceut Phytopharmacol Res 2: 412-4

Metz-Boutigue MH, Goumon Y, Strub JM, Lugardon K, Aunis D (2003) Antimicrobial chromogranins and proenkephalin-A-derived peptides: Antibacterial and antifungal activities of chromogranins and proenkephalin-A-derived peptides. Ann N Y Acad Sci 992: $168-78$

Mharti FZ, Lyoussi B, Abdellaoui A (2011) Antibacterial activity of the essential oils of Pistacia lentiscus used in Moroccan folkloric medicine. Nat Prod Commun 6: 1505-6

Mihailovic V, Vukovic N, Niciforovic N, Solujic S, Mladenovic M, Maškovic P, Stankovic MS (2011) Studies on the antimicrobial activity and chemical composition of the essential oils and alcoholic extracts of Gentiana asclepiadea L. J Med Plant Res 5: 1164-74

Miliukienė V, Nivinskas H, Čėnas N (2014) Cytotoxicity of anticancer aziridinyl-substituted benzoquinones in primary mice splenocytes. Acta Biochim Pol 61(4): 833-836

Minami S, Shono T, Matsumoto JI (1971) Pyrido [2, 3-d] pyrimidine Antibacterial Agents. I. 8Alkyl-5, 8-dihydro-5-oxopyrido [2, 3-d]-pyrimidine-6-carboxylic Acids and Related Compounds. Chem Pharm Bull 19(7): 1482-1486

Miyazawa M, Shimabayashi H, Hayashi S, Hashimoto S, Nakamura SI, Kosaka H, Kameoka H (2000) Synthesis and biological activity of $\alpha$-methylene- $\gamma$-lactones as new aroma chemicals. J Agri Food Chem 48: 5406-10.

Mjalli AM, Sarshar S, Zhang C (1998) U.S. Patent No. 5,723,451. Washington, DC: U.S. Patent and Trademark Office 
Moinet G, Correc JC, Arbellot De Vacqueur A. (2005) Acidic quinolines as antihyperglycemics and their preparation. Fr. Demande FR 2864535 A1 20050701

Mootha VK, Gohil V, Sheth S, Ji Y (2010) U.S. Patent Application 13/320,348

Morgan CA, Hurley TD (2015) Characterization of Two Distinct Structural Classes of Selective Aldehyde Dehydrogenase 1A1 Inhibitors. J Med Chem 58: 1964-75

Murthy YLN, Rajack A, Ramji MT, Praveen C, Lakshmi KA (2012) Design, solvent free synthesis, and antimicrobial evaluation of 1, 4 dihydropyridines. Bioorg Med Chem Lett 22: 6016-23

Musad EA, Mohamed R, Saeed BA, Vishwanath BS, Rai KL (2011) Synthesis and evaluation of antioxidant and antibacterial activities of new substituted bis (1, 3, 4-oxadiazoles), 3, 5-bis (substituted) pyrazoles and isoxazoles. Bioorg Med Chem Lett 21(12): 3536-3540

Nagarajan S, Choi MJ, Cho YS, Min SJ, Keum G, Kim SJ, Pae AN (2015) Tubulin Inhibitor Identification by Bioactive Conformation Alignment Pharmacophore-Guided Virtual Screening. Chem Biol Drug Design 86: 998-1016

Naseem T, Farrukh MA (2015) Antibacterial Activity of Green Synthesis of Iron Nanoparticles Using Lawsonia inermis and Gardenia jasminoides Leaves Extract. J Chem

Nemeikaitė-Čènienė A, Jarašienė R, Nivinskas H, Šarlauskas J, Čènas N (2015) Cytotoxicity of anticancer aziridinyl-benzoquinones in murine hepatome MH22a cells: the properties of RH1-resistant subline. Chemija 26(1) 
Niaz H, Kashtoh H, Khan JA, Khan A, Alam MT, Khan KM, Choudhary MI (2015) Synthesis of diethyl 4-substituted-2, 6-dimethyl-1, 4-dihydropyridine-3, 5-dicarboxylates as a new series of inhibitors against yeast $\alpha$-glucosidase. Eur J Med Chem 95: 199-209

Nidorf M (2015) U.S. Patent Application 14/603,085

Nordmann P, Naas T, Fortineau N, Poirel L (2007) Superbugs in the coming new decade; multidrug resistance and prospects for treatment of Staphylococcus aureus, Enterococcus spp. and Pseudomonas aeruginosa in 2010. Curr Opin Microbiol 10:436-40

Oberbauer E, Urmann C, Steffenhagen C, Bieler L, Brunner D, Furtner T, Aigner L (2013) Chroman-like cyclic prenylflavonoids promote neuronal differentiation and neurite outgrowth and are neuroprotective. J Nutri Biochem 24: 1953-62

Ohkawa S, Naruo K, Morimoto S, Nagase Y, Miwatashi S (2002) Medicinal compositions as p38MAP kinase and/or TNF-a production inhibitor for pain. PCT Int. Appl. WO 2002100433 A1 20021219

Okabe B (2015) Skin-whitening agent and melanin production inhibitor containing dihydroactinidiolide. Jpn. Kokai Tokkyo Koho JP 2015063496 A 20150409

O'Mahony MJ, West PJ, Lindell SD, Macritchie JA ((1997) Preparation of fungicidal pyridopyrimidines. Brit. UK Pat. Appl. GB 2307177 A 19970521

Ontoria JM, Altamura S, Di Marco A, Ferrigno F, Laufer R, Muraglia E, Jones P (2009) Identification of novel, selective, and stable inhibitors of class II histone deacetylases. 
Validation studies of the inhibition of the enzymatic activity of HDAC4 by small molecules as a novel approach for cancer therapy. J Med Chem 52: 6782-9

Orabi MA, Aoyama H, Kuroda T, Hatano T (2014) Structures of New Phenolics Isolated from Licorice, and the Effectiveness of Licorice Phenolics on Vancomycin-Resistant Enterococci. Molecul 19: 13027-41

Orhan I, Özçelik B, Karaoğlu T, Şener B (2007) Antiviral and antimicrobial profiles of selected isoquinoline alkaloids from Fumaria and Corydalis species. Zeit Natur 62: 19-26

Özbek N, Katırcıoğlu H, Karacan N, Baykal T (2007) Synthesis, characterization and antimicrobial activity of new aliphatic sulfonamide. Bioorg Med Chem 15: 5105-9

Özkay Y, Işıkdağ İ, İncesu Z, Akalın G (2010) Synthesis of 2-substituted-N-[4-(1-methyl-4, 5diphenyl-1H-imidazole-2-yl) phenyl] acetamide derivatives and evaluation of their anticancer activity. Eur J Med Chem 45: 3320-8

Pantosti A, Venditti M (2009) What is MRSA? Eur Respir J 34: 1190-6

Park KW, Kundu J, Chae IG, Kim DH, Yu MH, Kundu JK, Chun KS (2014) Carnosol induces apoptosis through generation of ROS and inactivation of STAT3 signaling in human colon cancer HCT116 cells. Int J Oncol 44: 1309-15

Parmar VS, Prasad AK, Raj HG, Bose M, Sharma SK, Tandon R, Baghel A, Kathuria A, Gupta G, Aggarwal Neha (2012) Coumarin compounds for the treatment of mycobacterial infections. Indian Pat. Appl. IN 2011DE00983 A 20121019

Pawelczap M, Nowak K, Kafarski P (1998) Synthesis of phosphono dipeptides, inhibitors of cathepsin C. Phospho Sulf Silic Rel Element 132: 65-71 
Pawellek A, McElroy S, Samatov T, Mitchell L, Woodland A, Ryder U, Lamond AI (2014) Identification of small molecule inhibitors of pre-mRNA splicing. J Biol Chem 289: $34683-98$

Pellecchia M (2008) Inhibitors of JNK, methods for identifying inhibitors of the JNK interaction with JIP (JNK-interacting protein), and use. PCT Int. Appl. WO 2008118626 A2 20081002

Perwitasari O, Johnson S, Yan X, Howerth E, Shacham S, Landesman Y, Tripp RA (2014) Verdinexor, a novel selective inhibitor of nuclear export, reduces influenza a virus replication in vitro and in vivo. J Virol 88: 10228-43

Pery E, Sheehy A, Nebane NM, Brazier AJ, Misra V, Rajendran KS, Gabuzda D (2015) Identification of a Novel HIV-1 Inhibitor Targeting Vif-dependent Degradation of Human APOBEC3G Protein. J Biol Chem 290: 10504-17

Peter OO, Lucky OO (2014) Design, Synthesis and Bioassay of Novel Metal Complexes of 3Amino-6, 8-Dibromo-2-Methyl Quinazolin-4 (3H)-One. Pharm Chem J 48: 718-21

Peyman A, Uhlmann E, Budt K, Knolle J, Winkler I, Helsberg M (1991) Preparation of benzylphosphonates as virucides. Eur. Pat. Appl. EP 440148 A1 19910807

Philip K (2014) In vitro antifungal activity screening of some new glutamoyl derivatives. Res J Chem Sci 4: 17-24

Piazza GA (2015) Treatment and diagnosis of cancer and precancerous conditions using pde10a inhibitors and methods to measure pde10a expression. PCT Int. Appl. WO 2015006689 A1 20150115 
Pisanenko DA, Smirnov-Zamkov YI, Novikov IN, Kovtun VK, Grib OK, Abramova KA (1986) Synthesis and pesticidal activity of esters of bis[4-(carboxymethoxy)phenyl] sulfone. Vest Kiev Politek Ins Khim Mash Tekhnol 23: 21-3

Puig-Basagoiti F, Qing M, Dong H, Zhang B, Zou G, Yuan Z, Shi PY (2009) Identification and characterization of inhibitors of West Nile virus. Antiviral Res 83(1): 71-79

Rademacher C, Guiard J, Kitov PI, Fiege B, Dalton KP, Parra F, Peters T (2011) Targeting norovirus infection - multivalent entry inhibitor design based on NMR experiments. Chem-Eur J 17: 7442-53

Raffa D, Maggio B, Cascioferro S, Raimondi MV, Daidone G, Plescia S, Tolomeo M (2009) N-(Indazolyl) benzamido Derivatives as CDK1 Inhibitors: Design, Synthesis, Biological Activity, and Molecular Docking Studies. Arch Pharmaz 342: 265-73

Rajagopal L, Howard KB, Whidbey C (2013) Kinase inhibitors capable of increasing the sensitivity of bacterial pathogens to b-lactam antibiotics. PCT Int. Appl. WO 2013066469 A2 20130510

Ramdani G, Naissant B, Thompson E, Breil F, Lorthiois A, Dupuy F, Cummings R, Duffier Y, Corbett Y, Mercereau-Puijalon O, Vernick K (2015) cAMP-signalling regulates gametocyte-infected erythrocyte deformability required for malaria parasite transmission. PLoS Pathog 11(5): e1004815

Rappai JP, Raman V, Unnikrishnan PA, Prathapan S, Thomas SK, Paulose CS (2009) Preliminary investigations on the synthesis and antitumor activity of $3(2 \mathrm{H})$-furanones. Bioorg Med Chem Lett 19: 764-5 
Rathore D, Jani D, Nagarkatti R (2007) HDP (heme detoxification protein) involved in hemozoin formation in Plasmodium and Theileria as an anti-protozoal target, and high-throughput screening for antimalarial HDP inhibitors. U.S. Pat. Appl. Publ. US 20070148185 A1 20070628

Rauf A, Uddin G, Khan H, Raza M, Zafar M, Tokuda H (2015) Anti-tumour-promoting and thermal-induced protein denaturation inhibitory activities of $\beta$-sitosterol and lupeol isolated from Diospyros lotus L. Nat Prod Res 30: 1205-7

Ray A, Boyle SM (2011) In silico screening method for identifying ligands for odor receptors and olfactory neurons for use as repellents in traps or other media. PCT Int. Appl. WO 2011130726 A2 20111020

Ren G, Sha T, Guo J, Li W, Lu J, Chen X (2015) Cucurbitacin B induces DNA damage and autophagy mediated by reactive oxygen species (ROS) in MCF-7 breast cancer cells. J Nat Med 69: 522-30

Richardson P, Campbell B (2015) Drug combination and its use in therapy of obesity comprising (2R)-Methyl-1-\{3-[2-(3-pyridinyloxy)ethoxy]-2-pyrazinyl $\}$ piperazine or vabicaserin and a sympathomimetic. PCT Int. Appl. WO 2015001359 A1 20150108

Richters A, Basu D, Engel J, Ercanoglu MS, Balke-Want H, Tesch R, Rauh D (2014) Identification and Further Development of Potent TBK1 Inhibitors. ACS Chem Biol 10: $289-98$ 
Rico A, Van den Brink PJ (2015) Evaluating aquatic invertebrate vulnerability to insecticides based on intrinsic sensitivity, biological traits and toxic mode-of-action. Environ Toxicol Chem 34: 1907-17

Riscoe MK, Kelly JX, Winter RW, Hinrichs DJ, Smilkstein MJ, Nilsen A (2011) U.S. Patent Application 13/153,347

Rosatelli E, Carotti A, Ceruso M, Supuran CT, Gioiello A (2014) Flow synthesis and biological activity of aryl sulfonamides as selective carbonic anhydrase IX and XII inhibitors. Bioorg Med Chem Lett 24: 3422-5

Roy NK, Taneja H (1989) Synthesis of aroyl phosphonates and oximes and their antifungal activity. Int J Trop Agri 6: 142-6

Ruckli R, Hesse K, Glauser G, Rusterholz HP, Baur B (2014) Inhibitory potential of naphthoquinones leached from leaves and exuded from roots of the invasive plant Impatiens glandulifera. J Chem Ecol 40(4): 371-378

Ryder S (2010) U.S. Patent Application 12/823,905

Sadek B, Al-Tabakha MM, Fahelelbom KMS (2011) Antimicrobial prospect of newly synthesized 1, 3-thiazole derivatives. Molecul 16: 9386-96

Sagheer M, Siddiqui R, Iqbal J, Khan NA (2014) Black cobra (Naja naja karachiensis) lysates exhibit broad-spectrum antimicrobial activities. Pathogen Glob Health 108: 129-36

Şahin G, Palaska E, Ekizoğlu M, Özalp M (2002) Synthesis and antimicrobial activity of some 1, 3, 4-oxadiazole derivatives. Il Farmaco 57: 539-42 
Sakunphueak A, Panichayupakaranant P (2012) Comparison of antimicrobial activities of naphthoquinones from Impatiens balsamina. Nat Prod Res 26(12): 1119-1124

Salas Vazquez DI, Rodriguez Jerez JJ, Osset Hernandez M, Montanes Izquierdo V (2014) Composition, kit and methods for control and elimination of biofilms. Span. ES 2464872 A1 20140604

Salzet M (2001) Vertebrate innate immunity resembles a mosaic of invertebrate immune responses. Trends Immunol 22: 285-8

Samadhiya P, Sharma R, Srivastava SK, Srivastava SD (2014) Synthesis and biological evaluation of 4-thiazolidinone derivatives as antitubercular and antimicrobial agents. Arab J Chem 7: 657-65

Sanchez TW, Debnath B, Christ F, Otake H, Debyser Z, Neamati N (2013) Discovery of novel inhibitors of LEDGF/p75-IN protein-protein interactions. Bioorg Med Chem 21: 957-63

Sasaki T, Myata H, Morikawa K (1996) Preparation of phosphonic acids as herbicide materials. Jpn. Kok Tok Koh JP 08034790 A 19960206

Savage PB, Li C (2000) Cholic acid derivatives: novel antimicrobials. Expert Opin Invest Drug 9: $263-72$

Schlewer G, Benezra C, Beck G, Beck JP (1979) The cytotoxic properties of g-mono-, b,g- and g,g-disubstituted a-methylene- g-butyrolactones. Toxicol Eur Res 2: 223-6

Schnatterer S, Maier M, Petry F, Knauf W, Seeger K (2009) Pesticidal substituted piperidines and their preparation. U.S. Pat. Appl. Publ. , US 20090082389 A1 20090326 
Seo YH, Han CH, Lee JM, Choi SM, Moon KD (2012) Effects of Opuntia ficus indica Extracts on Inactivation of Escherichia coli O157: H7 and Listeria monocytogenes on Fresh-cut Apples. J Kor Soc Food Sci Nutr 41: 1009-13

Shin HB, Choi MS, Ryu B, Lee NR, Kim HI, Choi HE, Inn KS (2013) Antiviral activity of carnosic acid against respiratory syncytial virus. Virol J 10: 303

Shiota C, Abe T, Kawai N, Ohno A, Teshima-Kondo S, Mori H, Nikawa T (2015) Flavones Inhibit LPS-Induced Atrogin-1/MAFbx Expression in Mouse C2C12 Skeletal Myotubes. J Nutr Sci Vitam 61: 188-94

Simon WA, Postius S, Riedel R, Senn-Bilfinger J, Grundler G (1998) Preparation of 7,8,9,10tetrahydroimidazo[1,2-h][1,7]naphthyridines for the prevention and treatment of. PCT Int. Appl. WO 9842707 A1 19981001

Sinam YM, Kumar S, Hajare S, Gautam S, Chatterjee S, Variyar PS, Sharma A (2012) Isolation and identification of antibacterial compound from Indo-Himalayan Aconitum nagarum. Asia Pac J Trop Dis 2: S878-82

Singh U, Raju B, Lam S, Zhou J, Gadwood RC, Ford CW, Zurenko GE, Schaadt RD, Morin SE, Adams WJ, Friis JM (2003) New antibacterial tetrahydro-4 (2H)-thiopyran and thiomorpholine S-oxide and S, S-dioxide phenyloxazolidinones. Bioorg Med Chem Lett 13(23): 4209-12

Sit SY, Xie K (2003) Bisarylimidazolyl fatty acid amide hydrolase inhibitors U.S. Patent No. $6,562,846$ 
Smetana H (1928) Studies upon the physiological action of hematoporphyrin. J Exp Med 47(4): $593-610$

Strobel H, Wohlfart P, Kleemann HW, Zoller G, Will DW (2008) Heteroarylacrylamides as endothelial nitric oxide synthase transcription modulators and their preparation and use as. PCT Int. Appl. WO 2008074413 A2 20080626

Su Z, Huang H, Li J, Zhu Y, Huang R, Qiu SX (2013) Chemical Composition and Cytotoxic Activities of Petroleum Ether Fruit Extract of Fruits of Brucea javanica (Simarubaceae). Trop J Pharm Res 12: 735-42

Sun JF, Lin X, Zhou XF, Wan J, Zhang T, Yang B, Yang XW, Tu Z, Liu Y (2014) Pestalols AE, new alkenyl phenol and benzaldehyde derivatives from endophytic fungus Pestalotiopsis sp. AcBC2 isolated from the Chinese mangrove plant Aegiceras corniculatum. J Antibiot 67(6): 451-7

Sun L, Quan H, Xie C, Wang L, Hu Y, Lou L (2014) Phosphodiesterase 3/4 Inhibitor Zardaverine Exhibits Potent and Selective Antitumor Activity against Hepatocellular Carcinoma Both In Vitro and In Vivo Independently of Phosphodiesterase Inhibition. PloS one $9(3)$

Sun XP, Cao F, Shao CL, Wang M, Zhang XL, Wang CY (2015) Antibacterial D1-3Ketosteroids from the South China Sea Gorgonian Coral Subergorgia rubra. Chem Biodiv 12: $1068-74$ 
Sunduru N, Agarwal A, Katiyar SB, Goyal N, Gupta S, Chauhan PM (2006) Synthesis of 2, 4, 6trisubstituted pyrimidine and triazine heterocycles as antileishmanial agents. Bioorg Med Chem 14: 7706-15

Suzuki M, Ueno M, Fukutomi R, Satoh H, Kikuchi H, Hagihara K, Noguchi Y (2000) U.S. Patent No. 6,096,746. Washington, DC: U.S. Patent and Trademark Office

Take Y, Inouye Y, Nakamura S, Allaudeen HS, Kubo A (1989) Comparative studies of the inhibitory properties of antibiotics on human immunodeficiency virus and avian myeloblastosis virus reverse transcriptases and cellular DNA polymerases. J Antibiot 42(1): 107-15

Tamao K, Minato A, Suzuki K, Kumada M, Tsujimoto K, Hamada M (1986) Heteroallene oligomer derivatives as fungicides. Jpn Kok Tok Koh JP 61037705 A 19860222

Tang Y, Ling J, Zhang P, Zhang X, Zhang N, Wang W, Li N (2015) Potential therapeutic agents for circulatory diseases from Bauhinia glauca Benth. subsp. pernervosa.(Da Ye Guan Men). Bioorg Med Chem Lett 25: 3217-20

Tangdenpaisal K, Worayuthakarn R, Karnkla S, Ploypradith P, Intachote P, Sengsai S, Chittchang M (2015) Designing New Analogs for Streamlining the Structure of Cytotoxic Lamellarin. Nat Prod.Chem-Asia J 10: 925-37

Tapia RA, Cantuarias L, Cuéllar M, Villena J (2009). Microwave-assisted reaction of 2, 3dichloronaphthoquinone with aminopyridines. J Braz Chem Soc 20: 999-1002 
Taylor PL, Rossi L, De Pascale G, Wright GD (2012) A forward chemical screen identifies antibiotic adjuvants in Escherichia coli. ACS Chem Biol 7: 1547-55

Tiuman TS, Ueda-Nakamura T, Alonso A, Nakamura CV (2014) Cell death in amastigote forms of Leishmania amazonensis induced by parthenolide. BMC Microbiol 14: 152

Tomizawa K, Wei F, Inoue K, Okawara T (2014) Therapeutic agent for type 2 diabetes containing specified benzene compound. PCT Int. Appl. WO 2014156196 A1 20141002

Tracey KJ, Al-Abed Y, Ivanova S, Bucala RJ (2000) Compounds and compositions for treating tissue ischemia. PCT Int. Appl. WO 2000003711 A1 20000127

Uesugi M, Wakil SJ, Al-Elheiga L, Watanabe M (2013) U.S. Patent Application 14/052,074

Uesugi M, Wakil SJ, Al-Elheiga L, Watanabe M (2013) U.S. Patent Application 14/013,918

Vance W, Kambam S (2007) U.S. Patent Application 11/676,805

Vassilev GN (1995) Growth regulating and herbicidal activities of benzylphosphonic acid derivatives obtained by the Ivanov reaction. Bulg Chem Comm 28: 231-45

Vennerstrom JL, Makler MT, Angerhofer CK, Williams JA (1995) Antimalarial dyes revisited: xanthenes, azines, oxazines, and thiazines. Antimicrob Agents Chem 39: 2671-7

Verbitskiy EV, Cheprakova EM, Slepukhin PA, Kravchenko MA, Skornyakov SN, Rusinov GL, Charushin VN (2015) Synthesis, and structure-activity relationship for C (4) and/or C (5) thienyl substituted pyrimidines, as a new family of antimycobacterial compounds. Eur J Med Chem 97: 225-34 
Vergara D, Simeone P, Bettini S, Tinelli A, Valli L, Storelli C, Maffia M (2014) Antitumor activity of the dietary diterpene carnosol against a panel of human cancer cell lines. Food Func 5: 1261-9

Villemagne B, Flipo M, Blondiaux N, Crauste C, Malaquin S, Leroux F (2014) Ligand Efficiency Driven Design of New Inhibitors of Mycobacterium tuberculosis Transcriptional Repressor EthR Using Fragment Growing, Merging, and Linking Approaches. J Med Chem 57: 4876-88

Wang H, Liang F, Zhang L (2015) Composition and anti-cyanobacterial activity of essential oils from six different submerged macrophytes. Pol J Environ Stud 24(1)

Wada K, Ohkoshi E, Zhao Y, Goto M, Morris-Natschke SL, Lee KH (2015) Evaluation of Aconitum diterpenoid alkaloids as antiproliferative agents. Bioorg Med Chem Lett 25: $1525-31$

Wang XD, Wei W, Wang PF, Yi LC, Shi WK, Xie YX, Wu LZ, Tang N, Zhu LS, Peng J, Liu C (2015) Synthesis, molecular docking and biological evaluation of 3-arylfuran-2 (5H)-ones as anti-gastric ulcer agent. Bioorg Med Chem 23(15): 4860-5

Wang XN, Jin T (2014) The clinical observation of ziprasidone and olanzapine for treating firstepisode schizophrenia. Chong Yix 43: 3527-9

Weaver JW, Jeroski EB, Goldstein IS (1959) Toxicity of dyes and related compounds to wooddestroying fungi. Appl Microbiol 7: 145-9 
Wei Y, Qiu G, Wang S (2015) Preparation of substituted 4,5-dihydropyrazolo[3,4-c]pyridine-2one derivatives for treating serine protease-related disease. PCT Int. Appl. WO 2015081901 A1 20150611

Weitz JI (2014). Expanding use of new oral anticoagulants. F1000 prime reports 6

Wilcke M, Svensson B, Walse B, Bengtsson T (2008) The use of naphthoquinones and related compounds in the treatment and control of diabetes, insulin resistance and hyperglycemia. PCT Int. Appl. WO 2008008033 A1 20080117

Wilson R, Chen C, Ratcliffe NA (1999) Innate immunity in insects: the role of multiple, endogenous serum lectins in the recognition of foreign invaders in the cockroach, Blaberus. discoidalis. J Immunol 162: 1590-6

Wirth S, Rohbogner CJ, Cieslak M, Kazmierczak-Baranska J, Donevski S, Nawrot B, Lorenz IP (2010) Rhodium (III) and iridium (III) complexes with 1, 2-naphthoquinone-1-oximate as a bidentate ligand: synthesis, structure, and biological activity. JBIC J Biol Inorg Chem 15: $429-40$

Wood JE, Baryza JL, Brennan CR, Choi S, Cook JH, Dixon BR (2002) Preparation of 4-phenylpyrrolidine-2-ones as 17-b-hydroxysteroid dehydrogenase-II inhibitors. PCT Int. Appl. WO 2002026706 A2 20020404

World Health Organization. Mortality Report. 2002; available at http://www.who.org Wynne GM, Wren SP, Lecci C (2008) Preparation of imidazopyridines and related compounds for the treatment of Duchenne muscular dystrophy. PCT Int. Appl. WO 2008029152 A2 20080313 
Yan J, Xiao L (2015) One kind of moringa leaves flavonoids extraction methods and their use. Fam Zhuan Shenq CN 104758325 A 20150708

Yang JY, Lee HS (2015) Antimicrobial activities of active component isolated from Lawsonia inermis leaves and structure-activity relationships of its analogues against food-borne bacteria. J Food Sci Tech 52(4): 2446-2451

Yang S, Zhang H, Beier RC, Sun F, Cao X, Shen J, Zhang S (2015) Comparative metabolism of Lappaconitine in rat and human liver microsomes and in vivo of rat using ultra highperformance liquid chromatography-quadrupole/time-of-flight mass spectrometry. J Pharm Biomed Anal 110: 1-11

Yang TC, Chao HF, Shi LS, Chang TC, Lin HC, Chang WL (2014) Alkaloids from Coptis chinensis root promote glucose uptake in C2C12 myotubes. Fitoterapia 93: 239-44

Yen CH, Chen SJ, Liu JT, Tseng YF, Lin PT (2013) Effects of Water Extracts of Graptopetalum paraguayense on Blood Pressure, Fasting Glucose, and Lipid Profiles of Subjects with Metabolic Syndrome. BioMed Research Int. 809234

Yin TP, Cai L, Fang HX, Fang YS, Li ZJ, Ding ZT (2015). Diterpenoid alkaloids from Aconitum vilmorinianum. Phytochem 116: 314-9

Youssef DT, Shaala LA, Alshali KZ (2015) Bioactive Hydantoin Alkaloids from the Red Sea Marine Sponge Hemimycale arabica. Marin Drug 13: 6609-19

Yuan CL, Wang XL (2012) Isolation of active substances and bioactivity of Aconitum sinomontanum Nakai. Nat Prod Res 26: 2099-102 
Yuan Y, Xu J (2015) Compositions and methods for treating herpesvirus infection. PCT Int. Appl. WO 2015081199 A1 20150604

Yuzhakov A (2011) U.S. Patent Application 13/118,317

Zampini IC, Arias ME, Cudmani N, Ordoñez RM, Isla MI, Moreno S (2013) Antibacterial potential of non-volatile constituents of Rosmarinus officinalis against 37 clinical isolates of multidrug-resistant bacteria. Bol. latinoam. Carib Plant Med Arom 12: 201-8

Zarzycka B, Seijkens T, Nabuurs SB, Ritschel T, Grommes J, Soehnlein O, Nicolaes GA (2015) Discovery of Small Molecule CD40-TRAF6 Inhibitors. J Chem Inform Mod 55: 294-307

Zemtsova MN, Zimichev AV, Trakhtenberg PL, Klimochkin YN, Leonova MV, Balakhnin SM, Bormotov NI, Serova OA and Belanov EF (2011) Synthesis and antiviral activity of several quinoline derivatives. Pharm Chem J 45(5): 267-269

Zender L, Wuestefeld T (2012) Small interfering RNA and other inhibitors of mitogen-activated protein kinase kinase 4 expression for liver regeneration and for treatment of liver failure. PCT Int. Appl. WO 2012136859 A1 20121011

Zhao Y, Yu QM, Wang JM (2014) The quantum chemical study on herbicidal activity of the ingredient from Flaveria bidentis (L) Kuntze. Guang Huag 42: 12-4

Zheng Q, Wang S, Liu W (2014) Discovery and efficient synthesis of a biologically active alkaloid inspired by thiostrepton biosynthesis. Tetrahedron 70(42): 7686-7690

Zhu M, Gao H, Wu C, Zhu T, Che Q, Gu Q, Li D (2015) Lipid-lowering polyketides from a soft coral-derived fungus Cladosporium sp. TZP29. Bioorg Med Chem Lett 25: 3606-9 


\section{Figure legends}

Figure 1. Crude extract from cockroach brains were prepared and tested (100 $\mu \mathrm{g})$ for antibacterial activity, as described in Materials and Methods. The results revealed that cockroach brain lysates exhibited more than $90 \%$ bactericidal activity against MRSA and neuropathogenic E. coli K1. For positive control, gentamicin $(100 \mu \mathrm{g}$ per $\mathrm{mL})$ exhibited more than $99 \%$ killed rate. The data is presented as the mean \pm standard mean of three independent experiments performed in duplicate. (B) Representative effects of crude extracts from cockroach brains on MRSA and neuropathogenic E. coli K1. Both MRSA and neuropathogenic E. coli K1 were treated with lysates for $2 \mathrm{~h}$ at $37^{\circ} \mathrm{C}$ for then plated on nutrient agar plates. Note that pretreatment of MRSA and neuropathogenic E. coli $\mathrm{K} 1$ exhibited bactericidal effects.

\section{Figure 2. Cockroach brain lysates inhibited methicillin-resistant Staphylococcus aureus} (MRSA)-mediated human brain microvascular endothelial cells (HBMEC) cytotoxicity. (A)

Cockroach brain lysates were prepared and tested for their protective effects against MRSAmediated cytotoxicity on HBMEC as described in Materials and Methods. Note that MRSA alone exhibited $>70 \%$ cell death. In contrast, MRSA pretreated with gentamicin or lysates for $2 \mathrm{~h}$ at $37^{\circ} \mathrm{C}$ and then incubated with HBMEC monolayers for $20 \mathrm{~h}$, exhibited minimal cell death. Likewise, $100 \mu \mathrm{g}$ of brain lysates alone had minimal cytotoxic effects on HBMEC. The data is presented as the mean \pm standard mean of three independent experiments performed in duplicate. (B) Representative effects of MRSA, lysates, gentamicin-treated MRSA, and lysates-treated MRSA on HBMEC monolayers for $20 \mathrm{~h}$. Pretreatment of MRSA with gentamicin did not produce visual disruption of HBMEC monolayers. Similar results were observed with lysates 
alone and MRSA pretreated with lysates. In contrast, HBMEC monolayers treated with MRSA exhibited complete monolayer disruptions. X200.

Figure 3. Cockroach brain and haemolymph lysates (water and methanol extractions) were subjected to LC-MS (Agilent Technologies 6460 Triple Quadrupole LC/MS) for qualitative analyses. The compounds were separated based on $\mathrm{m} / \mathrm{z}$ ratio and retention time in the column. The data obtained from the LC-MS for brain extract contained over 168 peaks from water extracted compounds (A), over 193 peaks from methanol-extracted compounds (B), and the data obtained from haemolymph extract contained over 182 peaks from water extracted compounds (C) and over 172 peaks from methanol-extracted compounds (D), and the data obtained from muscles extract contained over 180 peaks from water-extracted compounds (E) and over 190 peaks from methanol-extracted compounds (F). 